\title{
Wie kust Doornroosje wakker?
}

Citation for published version (APA):

Rozemeijer, F. A. (2009). Wie kust Doornroosje wakker? Maastricht University. https://doi.org/10.26481/spe.20090327fr

Document status and date:

Published: 27/03/2009

DOI:

10.26481/spe.20090327fr

Document Version:

Publisher's PDF, also known as Version of record

\section{Please check the document version of this publication:}

- A submitted manuscript is the version of the article upon submission and before peer-review. There can be important differences between the submitted version and the official published version of record.

People interested in the research are advised to contact the author for the final version of the publication, or visit the DOI to the publisher's website.

- The final author version and the galley proof are versions of the publication after peer review.

- The final published version features the final layout of the paper including the volume, issue and page numbers.

Link to publication

\footnotetext{
General rights rights.

- You may freely distribute the URL identifying the publication in the public portal. please follow below link for the End User Agreement:

www.umlib.nl/taverne-license

Take down policy

If you believe that this document breaches copyright please contact us at:

repository@maastrichtuniversity.nl

providing details and we will investigate your claim.
}

Copyright and moral rights for the publications made accessible in the public portal are retained by the authors and/or other copyright owners and it is a condition of accessing publications that users recognise and abide by the legal requirements associated with these

- Users may download and print one copy of any publication from the public portal for the purpose of private study or research.

- You may not further distribute the material or use it for any profit-making activity or commercial gain

If the publication is distributed under the terms of Article $25 \mathrm{fa}$ of the Dutch Copyright Act, indicated by the "Taverne" license above, 


\section{Maastricht University}

\section{Prof. dr. Frank Rozemeijer}

Faculteit der Economische Wetenschappen en Bedrijfskunde

Wie kust Doornroosje wakker? 
Wie kust Doornroosje wakker? 


\section{Colofon}

Design and print: Océ Business Services, Maastricht

ISBN: 9789056813093

NUR: 780

Alle rechten voorbehouden. Niets uit deze uitgave mag worden verveelvoudigd, opgeslagen in een geautomatiseerd gegevensbestand of openbaar gemaakt worden, zonder voorafgaande schriftelijke toestemming van de auteur of uitgever. 


\section{Wie kust Doornroosje wakker?}

In verkorte vorm uitgesproken bij de aanvaarding van het ambt van bijzonder hoogleraar Purchasing and Supply Management aan de Faculteit der Economische Wetenschappen en Bedrijfskunde van de Universiteit Maastricht.

Oratie voor de NEVI leerstoel Purchasing and Supply Management

Op 27 Maart 2009

Door Prof. dr. Frank Rozemeijer 
Wie kust Doornroosje wakker? 


\section{Inhoudsopgave}

I Ouverture $\quad 7$

II Het ontwaken van inkoop $\quad 11$

III Inkoop als wetenschap 17

IV Ontwikkelen van leveranciers relaties 23

$\checkmark$ Ontwikkelen van de inkoper 33

VI Conclusies $\quad 41$

Dankwoord 43

Referenties $\quad 47$ 
Wie kust Doornroosje wakker 


\section{I - Ouverture}

Mijnheer de Rector, Geachte Decaan, Waarde collega's, Geachte vertegenwoordigers van de NEVI, Beste vrienden, Lieve familie en Geachte overige aanwezigen,

Er was eens een directeur van een onderneming in nachtcrèmes, en zijn diepste wens was een concern inkoopafdeling. Op een congres komt de directeur een consultant tegen die voorspelt dat hij voor het einde van het jaar zo'n concern inkoopafdeling zal hebben. Na een lange voorbereiding zag de nieuwe concern inkoopafdeling het licht en gaf Sleeping Beauty BV een groot feest. De Directeur en de nieuw aangenomen Concern Inkoopdirecteur (of Chief Procurement Officer (CPO)) hadden alle dertien Business Unit directeuren persoonlijk uitgenodigd, op eentje na. Deze laatste had zich namelijk tijdens de voorbereidingen zo negatief uitgelaten over de kansen van een concern inkoopafdeling, dat hij in een vertrouwensconflict terecht was gekomen met de directie en vervolgens op non-actief was gesteld.

Op het feest gaven alle BU directeuren hun beste wensen voor de concern-inkoopafdeling; de een wenste haar veel besparingen toe, de ander een strategische rol binnen de onderneming, weer een ander goede relaties met leveranciers. Toen de $11^{\text {de }} \mathrm{BU}$ directeur uitgesproken was, kwam de op non-actief gestelde $13^{\mathrm{e}} \mathrm{BU}$ directeur binnenstormen en voorspelde dat binnen het jaar duidelijk zou worden dat Inkoop geen plek verdiende op het hoofdkantoor. Verder zou de CPO zich snijden aan het scherpe papier van een oud contract en vervolgens doodbloeden, waarop hij al glimlachend verdween. Dit was vanzelfsprekend een behoorlijke domper op de feestvreugde. Nu stapte de $12^{\mathrm{e}} \mathrm{BU}$ directeur naar voren, hij kon deze vloek helaas niet ongedaan maken, maar kon de dood wel veranderen in 100 jaar slaap, en niet alleen de CPO zou in slaap vallen maar de hele onderneming. En zo geschiedde. Vlak voordat de concern inkoopafdeling haar eerste verjaardag zou vieren, zwierf de CPO door de gangen van het hoofdkantoor en kwam per toeval in een verlaten spreekkamertje terecht waar een stokoude leverancier nog steeds zat te peinzen over een contract. De leverancier nodigde de CPO uit om naast hem te komen zitten en eens een blik te werpen op het wurgcontract, zoals hij het noemde. De CPO zat nog maar nauwelijks of 
zij sneed zich gemeen aan het scherpe papier van het contract waarop zij direct in een diepe slaap viel. Zoals voorspeld, verspreidde deze diepe slaap zich over het hele hoofdkantoor, van portier tot secretaresse en directeur. Nu niemand meer zorg droeg voor het hoofdkantoor groeide om het gebouw een steeds dichtere en ondoordringbare doornhaag waardoor leveranciers geen toegang meer hadden tot het hart van de onderneming. Zo gingen jaren en jaren voorbij. Vele leveranciers probeerden de CPO te bereiken om te laten zien welke waarde zij konden toevoegen aan Sleeping Beauty BV, maar zij allen verongelukten in de doornstruiken rond het hoofdkantoor.

De kenners onder $u$ zullen ongetwijfeld het sprookje hebben herkend. Enige gelijkenis met 'De schone slaapster' ((Perrault, 1667) in Bettelheim, 1993) of 'Doornroosje' ((Grimm, 1812) in Bettelheim, 1993) is niet toevallig. Naast dat ik als vader deze oratie interessant wil beginnen voor mijn twee jonge dochters is het ook zo dat er veel wijsheid verscholen ligt in sprookjes (Bettelheim, 1993). Sprookjes beschrijven vaak in uiteenlopende symboliek het proces dat een kind doormaakt om tot een volwassen persoonlijkheid uit te groeien. Terwijl bij de meeste sprookjes de nadruk ligt op grote daden die de helden moeten verrichten, is Doornroosje een sprookje waarbij passiviteit, van schijnbaar niets doen, het centrale symbolische motief is (Bettelheim, 1993). Een belangrijke les in dit sprookje is dat als we ons afkeren van de buitenwereld en we ons naar binnen keren, we geen persoonlijke groei meer kennen en ons bewustzijn niet ontwikkelen. Eigenlijk verkeren we dan, hoe mooi we aan de buitenkant ook zijn, in een soort permanente slaaptoestand. Pas wanneer Doornroosje zich weer voor de buitenwereld openstelt en een relatie met de prins aangaat, wordt ook wereld om haar heen weer wakker en levendig.

Ik hoor u denken, wat is nu je punt Frank, deze oratie zou toch over Inkoop gaan? Wel nu, dat gaat het ook. Het sprookje beschrijft een belangrijke fase in de ontwikkeling van de inkoopfunctie, namelijk die waarin een onderneming die bestaat uit meerdere business units besluit een concern inkoopafdeling op te bouwen. Precies op dit onderwerp ben ik in 2000 aan de TU Eindhoven gepromoveerd (Rozemeijer, 2000). Uit mijn onderzoek bleek dat het realiseren van concern inkoopvoordelen geen sinecure is. Net als in het sprookje is het niet eenvoudig om een goede CPO te vinden, om decentrale inkopers aan te zetten tot samenwerking, om BU directeuren te bewegen iets van hun autonomie af te staan en 
om leveranciers nieuwe concern contracten te laten tekenen. Komt een onderneming deze fase goed door dan is de weg vrij om door te groeien tot een volwassen inkoopfunctie. Maar, als in deze fase te veel nadruk blijft liggen op prijsonderhandelingen uitmondend in 'wurgcontracten' (zoals in het sprookje) dan zullen leveranciers zich afkeren en een verdere groei naar volwassenheid in de weg staan. Daarover later meer.

Ik ben van mening dat het sprookje geschikt is als metafoor om de ontwikkeling van inkoop als bedrijfskundig vakgebied te beschrijven. Inkoop is naar mijn mening de 'Sleeping beauty' van de Bedrijfskunde. Enerzijds geldt dit voor de praktijk, waar nog veel ondernemingen het potentieel van inkoop niet of maar slechts ten dele benutten. Anderzijds geldt dit ook voor de inkoopwetenschap. We zijn als inkoopwetenschappers nog te veel in onszelf gekeerd en weinig in staat om over de grenzen van ons eigen vakgebied heen te kijken. Ik kom daar graag later in mijn oratie meer op terug.

Dames en Heren,

Het is mij een eer en genoegen om de benoeming tot bijzonder hoogleraar Purchasing and Supply Management aan de Universiteit Maastricht te aanvaarden door middel van deze oratie.

Zoals bij de prins van Doornroosje, wil ik u, voor zover nodig, door middel van deze oratie proberen wakker te kussen en $u$ laten zien hoe mooi het inkoop vakgebied is. Gezien de grote diversiteit in achtergrond van de aanwezigen vandaag, zal de inhoud, vorm en toon van mijn betoog afwisselend academisch dan weer praktisch zijn.

Ik wil graag drie onderwerpen met $u$ bespreken vandaag. In de eerste plaats wil ik nader ingaan op wat inkoop is en hoe de inkoopfunctie zich ontwikkelt binnen bedrijven en in de wetenschap. Daarna wil ik het met $u$ hebben over hoe inkopers relaties kunnen opbouwen met leveranciers. Tenslotte wil ik stilstaan bij de mens achter de inkoper. Gedurende het verhaal zal ik regelmatig refereren aan de onderzoek en onderwijs activiteiten die we binnen de NEVI leerstoel in Maastricht uitvoeren. 


\section{II - Het ontwaken van inkoop}

Gedurendedelaatste decennia hebbenveel bed rijvenzich geheroriënteerd op hun kernactiviteiten en 'core competencies' (Prahalad en Hamel, 1990). Met als gevolg dat in toenemende mate activiteiten die als 'non core' werden bestempeld, werden uitbesteed aan toeleveranciers (van Weele en Rozemeijer, 1996). Het gemiddelde aandeel in de omzet dat wordt ingekocht is hierdoor navenant gestegen en ligt voor de industrie momenteel op 70\% (van Weele, 2005).

Uit het NEVI Purchasing Excellence onderzoek is gebleken dat als bedrijven op grote schaal best-practices op inkoopgebied zouden toepassen zij $10 \%$ van de inkoopuitgaven zouden kunnen besparen. Er is dus nog veel potentieel aanwezig. Echter, ondanks het feit dat er in de literatuur en in de praktijk veel aandacht wordt besteed aan de toegevoegde waarde van een meer strategische benadering van inkoop, wordt deze nog niet ten volle benut. Voormalig voorzitter van de NEVI, Jan Snijder, stelde in 2002 dat veel bedrijven in Nederland nog kosten bewusteloos zijn. Hij doelde hiermee op het feit dat er hoegenaamd geen aandacht wordt besteed aan het managen van de inkoopkosten (ELAN, 2002). Het is trouwens geen uniek Nederlands verschijnsel. Kerkhoff (2005) stoort zich aan het feit dat ook veel Duitse bedrijven geen oog hebben voor de potentiële toegevoegde waarde die leveranciers kunnen leveren en spreekt in dit kader over het 'slapende potentieel' van inkoop. Met andere woorden '... the beauty sleeps!' ook in Duitsland.

Het lijkt er dus op dat de we nog niet klaarwakker zijn in inkoopland. Maar, er is goed nieuws, de prins lijkt op komst! Het Financiële Dagblad kopte ruim een jaar geleden (29-12-2007: p. 20).

\section{"Afdeling Inkoop heeft de toekomst"}

Mede ingegeven door de toenemende schaarste op diverse markten stelt het FD dat er een belangrijke taak ligt voor de afdeling inkoop in het zekerstellen van grondstoffen. Deze boodschap werd opgetekend uit de monden van diverse inkoopprofessionals en -collega NEVI Inkoophoogleraren. Het is opvallend te noemen dat het FD pas in 2007 komt met een dergelijke kop. We weten immers al jaren dat 
Inkoop de toekomst. Sinds Michael Leenders in 1963 promoveerde op het onderwerp Supplier Development en daarmee de basis legde voor inkoop als wetenschappelijke discipline, worden we daar ieder decennium wel weer aan herinnerd (Ammer, 1974; Ribbers, 1980; Kraljic, 1983; Van Weele, 1990; Nooteboom, 1996; Farmer, 1997).

Is het dan zo erg in Nederland? Ik zou durven te stellen dat er diverse bedrijven zijn waar op dit moment sprake is van een (hernieuwd) ontwaken op inkoopgebied. De Economische recessie waar we nu inzitten gaat dat proces zeker versnellen. De waarde van het geld zal worden herontdekt bij veel bedrijven met als direct gevolg dat strenger gekeken zal gaan worden naar de uitgavenkant. Het tijdsgewricht lijkt in dit opzicht wel wat op het tijdsgewricht begin tachtiger jaren toen Kraljic (1983) de basis legde voor zijn beroemde inkoopportfolio. Toen hadden we oliecrisis, economische crisis en de Club van Rome, die ertoe leidde dat er meer aandacht voor inkoop kwam. Nu hebben we een financiële crisis, Al Gore en een economische recessie. Het lijkt er sterk op dat de belangstelling voor het inkoopvak anti cyclisch is: hoe slechter het gaat met de economie, des te beter gaat het met inkoop.

Hoe wakker zijn bedrijven in Nederland als het gaat om inkoop? Om deze vraag precies te beantwoorden zal ik eerst bepalen wat inkoop is en vervolgens aangeven wat 'wakker' is.

Na 15 jaar werkzaam te zijn in inkoopland is het voor mij nog steeds niet eenvoudig om inkoop te definiëren. Dit komt omdat het nog een relatief jong vakgebied betreft dat nog steeds sterk in ontwikkeling is. Er bestaan vele definities, die uiteenlopen van betrekkelijk eenvoudig en praktisch, zoals 'Inkoop betreft alles waar een factuur van derden tegenover staat' (Telgen, 1994), tot zeer uitgebreid. Hoewel de verleiding groot is, kies ik ervoor in deze oratie geen gedetailleerde discussie over definities te voeren, dat hebben mijn collega's al heel goed gedaan in hun oraties (Van Weele, 1990; Telgen, 1994, Van Weele, 1994; Vos, 2004; Harink, 2005; Wynstra, 2006; Reijners, 2006).

Inkoop is een vakgebied met vele facetten. Niet alleen het goed doorlopen van het inkoopproces is van belang, maar ook het opbouwen en onderhouden van relaties met leveranciers. Graag volg ik daarom de definitie van Wynstra (2006) die stelt dat Inkoop en Leveranciers Management... 
...het inrichten, initiëren, sturen, en controleren van activiteiten binnen en tussen organisaties betreft die gericht zijn op het betrekken van goederen en diensten van externe leveranciers.

Het expliciet benoemen van activiteiten binnen en tussen organisaties spreekt mij aan. Uiteindelijk gaat het in inkoop om het realiseren van economische transacties tussen organisaties. Dat is ook het beeld dat veel mensen hebben van inkoop, dat het gaat over onderhandelen, contracteren en samenwerken met externe partijen. Uit eigen onderzoek blijkt dat het interne stuk van inkoop (overleg met interne klanten, het coördineren van inkoop over verschillende bedrijfsonderdelen en dergelijke) vaak de meeste tijd en inspanning vraagt (Rozemeijer, 2000; Rozemeijer et.al., 2003; Van Weele et al, 2005). Onderzoek toont aan dat inkopers 20 tot 30\% van hun tijd besteden aan externe communicatie met leveranciers, de rest van de tijd vind de communicatie intern plaats (Large, 2005).

$\mathrm{Nu}$ ik heb aangegeven wat ik onder inkoop versta, zal ik aangeven wat 'wakker' is en wat niet.

Er zijn bedrijven die als geheel in diepe slaap verkeren op het gebied van inkoop, waar het management zich niet bewust is van de potentie van inkoop. In dat geval zien we helemaal geen inkoopafdeling of maximaal een introverte inkoopafdeling die sterk gericht is op het eigen functioneren. Het inkoopbeleid, als dat er al is, staat los van de bedrijfsstrategie en men concentreert zich vooral op operationele inkoopaspecten. Als we daarnaast een bed rijf zetten dat klaarwakker is op het gebied van inkoop, dan zien we daar een professionele en volwassen inkoopfunctie die kan rekenen op top management betrokkenheid en waar met name in crossfunctionele teams gewerkt wordt. We zien dat de inkoopstrategie volledig is afgestemd op de bedrijfsstrategie (i.e. er is sprake van wat we noemen 'strategic alignment') en dat leveranciers een grote bijdrage kunnen leveren aan de concurrentie kracht van de onderneming.

Om te kunnen analyseren hoe de inkoopfunctie van een bedrijf zich in de tijd ontwikkelt heb ik samen met collega Van Weele een conceptueel model ontwikkeld. Dit model beschrijft zes fasen die een inkoopfunctie kan doorlopen (Rozemeijer et al, 1998). Met een beetje fantasie, en ik hoop van harte dat u dat heeft, zou u hierin ook het proces van ontwaken 
kunnen zien. Vanuit de diepe slaaptoestand doorlopen bedrijven achtereenvolgens de zes fasen tot die van 'waarde keten oriëntatie'. In deze laatste fase zijn bedrijven klaarwakker, staan alle zintuigen op scherp en is men alert op kansen die zich voordoen op zowel toeleverals afzetmarkten. Hieronder zal ik iedere fase kort beschrijven.

1) Transactionele oriëntatie: In deze fase ontstaat het eerste besef dat het toch wel verstandig is om het bestellen administratief correct af te handelen om misverstanden met leveranciers rond levertijden en betalingen te voorkomen. Er worden bestellers aangesteld die puur administratief en operationeel inkoopwerk uitvoeren.

2) Commerciële oriëntatie: In deze fase ontstaat een inkoopafdeling waarbij inkopers, onafhankelijk van de interne klant, de taak krijgen voor bepaalde inkoopprojecten meerdere offertes aan te vragen, prijzen met elkaar vergelijken en met de laagste aanbieder verder te onderhandelen om zo prijsverlagingen te realiseren. Hier ontstaat het inkoopvak zoals velen het kennen. Het algemeen management is in deze fase met name geïnteresseerd in de besparingen en niet zozeer in hoe die behaald worden.

3) Synergetische oriëntatie: In deze fase wordt voor de hele onderneming nauwgezet geïnventariseerd wat de totale inkoopuitgaven zijn en met welke leveranciers zaken worden gedaan. Zogenaamde category sourcing teams sluiten voor de belangrijkste inkoopsegmenten concernbrede raamcontracten af en realiseren daarmee inkoopsynergie. In deze fase ontstaat de concern inkoopafdeling, zoals beschreven in het sprookje van Sleeping Beauty BV.

Aan het einde van fase drie is de inkoopfunctie uitgegroeid tot een respectabele functie, maar heeft het nog bij lange na niet het volle potentieel kunnen laten zien. De overgang van fase 3 naar fase 4 is een lastige overgang die voor sommige ondernemingen wel jaren kan duren, als ze er al aan toekomen. Om door te groeien naar fase 4 en verder zal het hele bedrijf moeten ontwaken en betrokkenheid moeten gaan tonen bij de inkoopfunctie, niet in de laatste plaats het topmanagement.

4) Crossfunctionele oriëntatie: in deze fase wordt het management zich ervan bewust dat de grootste besparingen te behalen zijn door te kijken naar de specificaties. Intensieve samenwerking tussen 
verschillende afdelingen (bv. R\&D, Marketing, Productie, Logistiek) is noodzakelijk is om verdere verbeteringen van de total cost of ownership te realiseren. In deze fase komt ook de samenwerking met de 'first tier' leveranciers op gang.

5) Toeleverketen oriëntatie: nadat men in staat is om intern effectief samen te werken komt in deze fase van ontwaken de focus te liggen op verregaande uitbesteding en het zeer intensief samenwerken met $1^{\text {ste }}, 2^{\text {de }}$ en $3^{\text {de }}$ lijn leveranciers. Het doel in deze fase is om in de hele keten de totale kosten te verlagen, de waarde te maximaliseren en de risico's te beperken.

6) Waardeketen oriëntatie: in deze fase is alles gericht op het leveren van maximale waarde aan de eindconsument. Leveranciers en klanten worden maximaal betrokken bij de ontwikkeling van nieuwe producten ('open innovatie') en bij de ontwikkeling van nieuwe markten (business development). Omdat risico's en opbrengsten uit deze samenwerking vooraf niet duidelijk gekwantificeerd kunnen worden, spreken we hier van 'Ondernemend Samenwerken' (Van Weele en Rozemeijer, 1999).

Figuur 1 Inkoop ontwikkelmodel (Rozemeijer et al, 1998)

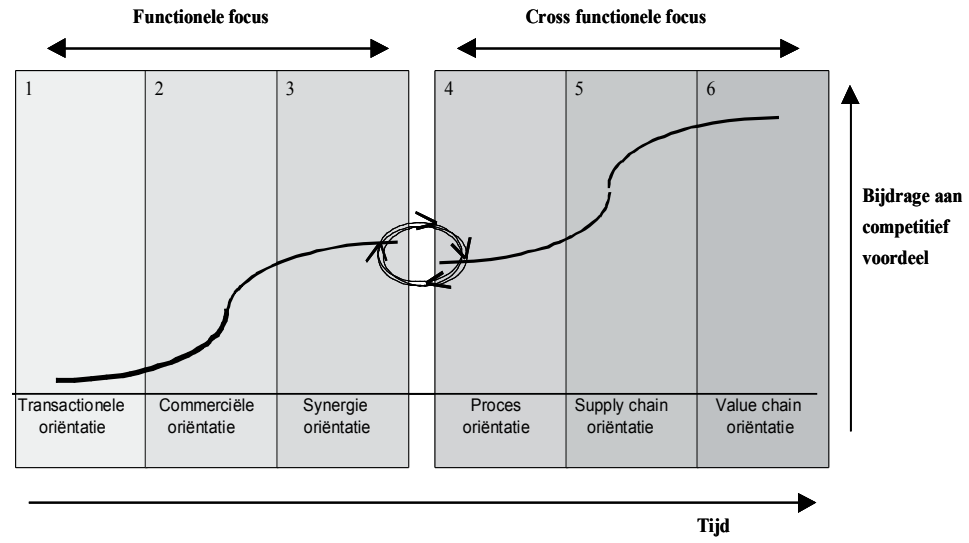

Tijdens colleges en in-company workshops wordt regelmatig de vraag aan mij gesteld hoe snel ondernemingen deze fasen kunnen doorlopen. Het antwoord hangt natuurlijk af van de daadkracht van de direct betrokkenen, i.c. de verantwoordelijke inkoopleidinggevende, maar ook van de bereidheid bij het management om wijzigingen in de organisatie en de tot dan toe gehanteerde werkwijzen aan te brengen. Niet zelden 
moeten 'heilige huisjes' tot de grond toe worden afgebroken voordat de inkoopfunctie kan doorgroeien naar een volgende fase. Op grond van vele praktijkobservaties is mij gebleken dat de ontwikkeling van de inkoopfunctie gemiddeld genomen rond de 3 jaar per fase kost. Het is dus langzaam wakker worden in inkoop.

Het betreft hier een conceptueel model waarop kritiek mogelijk is en die is er ook. Ramsey en Croom (2008) hebben hun kritiek onlangs geventileerd in het Journal of Purchasing and Supply Management. Kort gezegd komt hun kritiek hierop neer dat zij weinig toegevoegde waarde zien in dergelijke ontwikkelmodellen omdat ze een te simplistische weergave van de werkelijkheid geven. Verder hebben ze moeite met het feit dat deze modellen conceptueel van aard zijn en niet grondig empirisch zijn getoetst. In mijn repliek in hetzelfde journal geef ik aan dat er inderdaad weinig toetsing heeft plaatsgevonden en dat nader longitudinaal onderzoek nodig is om dit model verder wetenschappelijk te toetsen (Rozemeijer (2008), maar dat dit model gezien haar populariteit in de praktijk toch een grote praktische relevantie heeft. Dit ontwikkelmodel blijkt, zoals vele inkoopmanagers hebben aangegeven, effectief als denkkader en hulpmiddel voor bedrijven om te bepalen waar zij vandaag staan en waar zij naartoe willen. De komende jaren zal ik mij blijven inspannen om dit model verder uit te werken en te valideren. Een onderzoeksvraag die ik relevant vind is bijvoorbeeld de vraag of het ontwikkelen van de inkoopfunctie afhankelijk is van het leiderschap binnen de inkoopfunctie, de visie en ontvankelijkheid van het top management of van de ondernemingscultuur of een combinatie van die factoren. De goede verstaander hoort in deze onderzoeksvraag direct de vraag 'Wie kust Doornroosje wakker?'. Met uw permissie kom ik daar later op terug. 


\section{Deel III - Inkoop als wetenschap}

Hoewel velen van $u$ waarschijnlijk direct zullen toegeven niet goed te zijn in verkopen, verwacht ik dat u zichzelf wel zult zien als een goede inkoper. "Wat is er nou wetenschappelijk aan het uitgeven van geld", zo wordt mij wel eens gevraagd door niet vakgenoten. "Dat kan toch iedereen?", wordt er dan vaak nog aan toegevoegd. Het blijkt vaak dat Inkoop een beetje als het weer is, bijna iedereen heeft er een mening over. Begrijpelijk, want wie doet het niet; een dagje shoppen in de stad, boeken bestellen via Internet, boodschappen doen bij de supermarkt of een auto aanschaffen of zelfs een huis kopen? We redden ons best zonder inkoper aan onze zijde en in de meeste gevallen is dat uitgeven van geld nog leuk ook.

Maar, in het bedrijfsleven ligt dat anders, daar geldt:

"De cost gaet voor de baet uyt"

Dit gezegde tekent de Nederlandse koopmansgeest uit de VOC periode. Koopmannen uit die tijd begrepen heel goed dat inkoop en winst nauw samenhangen en dat het onvermijdelijk is om eerst geld uit te geven voordat je wat kunt gaan verdienen. En...

...Geld uitgeven is een strategische activiteit, en moet worden gedaan door topprofessionals die weten waar zij het over hebben", aldus Marc Hermans, CPO van Barco, in een interview in Deal! (Andriesse, 2008).

Deze opmerking maakt het in mij ogen relevant om wetenschappelijk onderzoek te doen naar "...hoe je het beste geld uitgeeft", om de woorden van Hermans te gebruiken.

Inkoop is geen basiswetenschap zoals bijvoorbeeld Economie, Psychologie en Wiskunde dat zijn, maar een toepassingsdomein voor deze meer fundamentele wetenschappen. Binnen het inkoopdomein zijn vooral (technisch) Bedrijfskundigen actief en in mindere mate vinden we daar ook Economen, Sociologen en Wiskundigen. 
Wynstra (2006) geeft in zijn oratie aan dat er binnen de Bedrijfskunde primair vier vakgebieden zijn die zich (deels) bezighouden met onderwerpen op het gebied van inkoop en leveranciersmanagement:

1. Marketing

2. Strategy \& Organization

3. Operations Management

4. Operations Research.

Tabel 1 Aantal artikelen over de periode $1999-2003$ (Wynstra, 2006)

$\begin{array}{lrr}\text { Vakgebied } & \text { Aantal artikelen } & \text { ILM intensiteit } \\ \text { Marketing } & 188 & 10,2 \% \\ \text { Strategy \& Organization } & 68 & 1,9 \% \\ \text { Operations Management } & 358 & 8,1 \% \\ \text { Operations Research } & 180 & 2,9 \% \\ & 794 & \end{array}$

Tabel 1 toont aan dat op grond van het aantal publicaties gesteld kan worden dat Marketing en Operations Management het meest prominent zijn in hun aandacht voor ons vakgebied. Ze zijn samen goed voor bijna $70 \%$ van het totaal aantal gevonden artikelen. Hoezeer deze vier vakgebieden ook bijdragen aan de ontwikkeling van het vakgebied, er mist in mijn beleving in deze lijst nog een vijfde vakgebied te weten de sociale en gedragswetenschappen (o.a. Psychologie en Sociologie).

Het is mijn persoonlijke overtuiging dat binnen het wetenschappelijke inkooponderzoek de sociale en gedragsmatige aspecten nog relatief onderbelicht zijn gebleven. Als we de JPSM en JSCM van de afgelopen 10 jaar erop naslaan, dan is de oogst zowel kwantitatief als kwalitatief mager. Om te verkennen of dergelijk onderzoek wellicht wel is uitgevoerd, maar direct is gepubliceerd in de gedragswetenschappelijke journals heb ik een literatuurverkenning uitgevoerd binnen een aantal bekende journals (o.a. Journal of Applied Psychology, Journal of Business and Psychology, Group and Organization Management, Human Resource Management). Het blijkt dat er over de periode 1995 tot en met 2008 slechts 12 artikelen zijn gepubliceerd met Inkoop als toepassingsdomein (zie tabel 2 hieronder). Voor zover ik kan beoordelen zijn al deze artikelen geschreven door onderzoekers die niet uit het inkoopvak komen. 
Tabel 3 Aantal artikelen in social sciences journals (periode 1995-2008)

\begin{tabular}{|l|r|}
\hline Journal & Aantal artikelen \\
\hline European Journal of Work and Organizational Psychology & 0 \\
Group and Organization Management (GOM) & $3(1999,2001,2007)$ \\
Human Resource Management (HRM) & $1(2003)$ \\
Human Resouce Management Journal (HRMJ) & $1(2000)$ \\
Human Resource Development Review & 0 \\
Int. Journal Of Training and Development (IJTD) & $1(2005)$ \\
Journal of Applied Psychology (JAP) & $1(2005)$ \\
Journal of Business and Psychology (JBP) & $1(1995)$ \\
Journal of Managerial Psychology & 0 \\
Journal of Occupational and Organizational Psychology & 0 \\
Journal of Organizational Behavior (JOB) & $1(2000)$ \\
Journal of Organizational Change Management & 0 \\
Leadership \& Organization Development Journal & 0 \\
Leadership Quarterly & $(2005,2006,2006)$ \\
Personnel Psychology & 0 \\
Research in Organizational Behavior & 0 \\
\hline Totaal & 0 \\
\hline
\end{tabular}

Als we de twaalf artikelen nader bekijken dan zijn deze onder te brengen in de volgende drie thema's:

\section{a) De mens achter de inkoper}

Humphrey et.al. (2000: JOB) tonen in hun onderzoek aan dat inkopers hun emotionele uitingen aanpassen aan de leverancier die ze tegenover zich hebben (strategisch of niet) en de inkoopstrategie die ze hebben geformuleerd. Keaveney (1995: JBP) heeft onderzoek gedaan naar de motivatie van inkopers. Conclusie uit dit onderzoek is dat intrinsiek gemotiveerde inkopers meer informatie raadplegen, vaker nieuwe leveranciers vinden en minder fouten maken. Een pleidooi dus voor het selecteren van inkopers met passie voor het inkoopvak.

\section{b) Vertrouwen tussen inkoper en leverancier}

Er wordt veel gepubliceerd over het onderwerp vertrouwen in de gedragswetenschappelijke journals. Specifiek toegepast op het thema leveranciers relaties zijn er drie artikelen te vinden. Alvarez et.al. (2003: HRM), Lehtonen (2006: LODJ) en Sengun et.al. (2007: GOM) tonen aan dat vertrouwen belangrijk is voor het aangaan van effectieve relaties met 
leveranciers, maar dat vertrouwen alleen niet genoeg is. Vertrouwen werkt goed in combinatie met controle mechanismen zoals contracten, reputatie en onderhandelingskracht. Wong et.al. (2005: JAP) tonen aan dat opportunistisch gedrag in buyer-supplier relaties verminderd kan worden door samen met leveranciers te werken aan een gedeelde visie en gezamenlijke doelstellingen.

\section{c) Onderhandelen}

Binnen de gedragswetenschappen wordt ook veel onderzoek gedaan naar onderhandelingsprocessen. Karakowski et.al. (2006: LODJ) stellen dat vrouwen zich in een door mannen gedomineerd team anders gedragen tijdens onderhandelingen dan vrouwen in een door vrouwen gedomineerd team. Olk et.al. (2001: GOM) komen tot de conclusie dat vriendschappelijke relatie tussen degenen die onderhandelen van weinig invloed is op de uiteindelijke vorm van de samenwerking tussen die twee partijen. Butler (1999: GOM) heeft onderzoek gedaan naar de impact van het vertrouwensklimaat en de hoeveelheid informatie die gedeeld wordt op de effectiviteit en efficiency van onderhandelingen. Het blijkt dat de mate van informatiedeling een groter positief effect heeft dan het vertrouwensklimaat.

Gebaseerd op mijn bevindingen kom ik tot de conclusie dat de sociale en gedragswetenschappen een interessante 'body of knowledge'bevat voor inkoopwetenschappers. Er zit veel kennis oponderwerpen alsvertrouwen, groepsgedrag, emotie, cultuur, samenwerking en onderhandelen, maar zeker ook op het vlak van methodologie valt er iets te leren (Tazelaar, 2007). Die kennis zouden wij goed kunnen inzetten op vraagstukken rond samenwerking met leveranciers in toeleverketens, maar ook op vraagstukken die binnen de inkooporganisatie liggen. Ik ben van mening dat dit kan leiden tot een verrijking van de 'body of knowledge' binnen inkoop. Net als collega Tazelaar (2007), zelf een socioloog, ben ik van mening dat we als inkooponderzoekers wel wat meer samenwerking mogen opzoeken met collega's uit de sociale disciplines. Op dit moment wordt naar mijn mening het sociale en gedragsmatige wiel te veel opnieuw uitgevonden door inkoopwetenschappers en ik moet eerlijk toegeven dat ik mij daar ook schuldig aan maak. Vaak zijn die 'inkoop wielen' niet van dezelfde kwaliteit als de wielen van de echte specialisten. Met als gevolg dat dit onderzoek niet gepubliceerd kan worden in de eerder genoemde journals uit de sociale wetenschappen. Deze journals hebben hoge SSCI ratings (bv. Journal of Applied Psychology) 
en de eisen aan manuscripten zijn navenant. Des te meer reden om de samenwerking op te zoeken.

In welke richting ontwikkelt het inkoopvak zich in de toekomst? Wat is de research agenda voor de komende jaren? Om hier een mening op te formuleren, maak ik graag gebruik van de toekomstverkenning van het Amerikaanse Centre for Advanced Purchasing Studies (CAPS, 2007). Er zijn meerdere toekomstverkenningen beschikbaar, maar die zijn veelal geproduceerd door grote consultancy bedrijven (o.a. Accenture, IBM) en dat maakt ze minder objectief. Een andere reden om te kiezen voor het CAPS onderzoek is het feit dat de resultaten gebaseerd zijn op de input van een groot aantal respondenten $(n=260)$ afkomstig vanuit de hele wereld.

Tabel 3 Acht trends voor de toekomst van Inkoop (CAPS, 2007)

- Developing category strategies

- Designing and operating multiple supply networks

- Develop and manage value-adding relationships with suppliers

- Collaborating internally across functions

- Collaborating externally with suppliers and customers

- Attracting and retaining Supply Management talent

- Leveraging technology enablers

- Managing and enabling the Supply Management organization

Wat uit dit onderzoek naar voren komt is de verwachting dat er zowel intern als extern meer samengewerkt zal gaan worden in de toekomst. Intern zal intensiever samengewerkt gaan worden met andere functionele disciplines, bijvoorbeeld bij het vaststellen van specificaties. Extern zal meer met leveranciers en klanten worden samengewerkt bij het ontwikkelen van nieuwe producten en verbetering van processen. In termen van het inkoop ontwikkelmodel spreken we hier van kenmerken uit fase 4 en 5 . Supplier Relationship Management (SRM) zal naar het oordeel van de respondenten hoog op de agenda van de toekomst moeten staan. In de CAPS study heeft het thema Improving working relationships with strategic suppliers zelfs de hoogste gemiddelde score gekregen (4,42 op een 5-punts schaal) van alle toekomst trends.

Het zijn uiteindelijk mensen die bepalend zijn voor een goede 
samenwerking tussen twee organisaties. Daarom voorspel ik voor de komende jaren meer aandacht voor de menskant binnen de inkoopfunctie. Erzal meer begrip opgebouwd moeten worden over welke sociale en relationele vaardigheden nodig zijn. Volgens de CAPS studie wordt het vinden en binden van mensen met deze vaardigheden door de respondenten al expliciet benadrukt als trend voor de toekomst.

Aan beide thema's wil ik vanuit de NEVI leerstoel aandacht besteden, zowel door middel van onderwijs als door middel van onderzoek. Ik zal beginnen met mijn observaties en visie op gebied van het ontwikkelen van leveranciers relaties. 


\section{Deel IV - Ontwikkelen van leveranciers relaties}

Sinds mijn afstudeeronderzoek naar uitbestedingsrelaties binnen de onderhoudsector in de Nederlandse industrie (Rozemeijer, 1994) ben ik geïnteresseerd in de vraag hoe bedrijven samenwerken met leveranciers (Rozemeijer,1995; Van Weele \& Rozemeijer, 1999). Samenwerking met leveranciers wordt in meer en meer industrietakken gezien als een belangrijke voorwaarde voor succes, maar is bepaald niet vanzelfsprekend (CAPS, 2007, Welling, 2006). Het is makkelijker gezegd dan gedaan.

Ik wil graag voordat ik de diepte in ga, drie praktijkcases uit de automobiel industrie naast elkaar zetten.

In 2000 kondigde Toyota het CCC21 Programma (Construction of Cost Competitiveness for the 21st Century) aan waarmee de inkoopkosten voor de 180 belangrijkste auto onderdelen met 30\% omlaag gebracht moesten worden. Het programma richtte zich op het reduceren van complexiteit van specificaties, benchmarking met leveranciers in China en het vergroten van de leveranciersbasis. CCC21 heeft Toyota geen windeieren gelegd met meer dan 10 miljard dollar aan kosten besparingen in de periode 2000-2005. Het programma heeft tevens geresulteerd in een verbetering van de kwaliteit van de onderdelen (Dawson, 2005). Het behoeft geen nader betoog dat dit programma veel aanpassingen en investeringen vergde van de leveranciers, maar toch bleken ze het programma niet als unfair te zien. Ze hebben, uitzonderingen daargelaten, positief gereageerd en zijn gemotiveerd de uitdaging aan gegaan. Volgens Liker et al (2004) was dat met name te wijten aan het feit dat ze wisten dat ze konden rekenen op de steun en loyaliteit van Toyota en omdat ze wisten hiermee uiteindelijk competitiever en winstgevender te zullen worden.

Dit voorbeeld staat in schril contrast met de manier waarop Ignacio Lopez als nieuwe CPO van GM in 1992 de inkoopkosten met tenminste $20 \%$ wilde verlagen. Zijn inkoopstrategie leidde tot veel rumoer onder de leveranciers. Bestaande meerjaren contracten die net getekend waren, werden door Lopez verscheurd en vervangen door korte termijn contracten met 'goedkopere' leveranciers. Lopez dwong leveranciers tot gehoorzaamheid, de leverancier volgde de wensen van GM of anders 
kon de leverancier vertrekken. In de eerste negen maanden dat Lopez actief was bij GM werd meer dan $25 \%$ van de ingekochte onderdelen opnieuw gesourced en veelal bij andere leveranciers neergelegd. Hij bespaarde op deze manier veel geld voor GM (alleen al 300 miljoen dollar in 1992) maar veroorzaakte met zijn aanpak ook veel kwaliteitsen leveringsproblemen. Heiligt het doel de middelen? Op de vraag of hij zich wel eens afvroeg hoe Lopez die resultaten toch behaalde, stelde Bob Eaton (voormalig CEO van GM Europe en de man die Lopez had aangenomen) "I never bothered to ask how he got the results he did; I just counted them up" (Stallkamp, 2005). Voor deze CEO heiligt het doel blijkbaar de middelen.

Is de Toyota benadering alleen voor Japanse ondernemingen geschikt? Het antwoord is nee. Het bewijs hiervoor werd geleverd door Chrysler (Dyer, 1996). In 1990 kwam bij Chrysler een nieuwe CPO aan het roer, Thomas Stallkamp. Hij startte het SCORE programma dat gericht was op het reduceren van kosten in de hele keten. In plaats van het afdwingen van kostenreducties op een agressieve manier koos Stallkamp, met het volledige mandaat van zijn CEO, een radicaal andere benadering dan GM en Ford. Mede geïnspireerd door het voorbeeld van Honda of America (Van Weele \& Rozemeijer, 1996), waar Stallkamp en zijn mensen in de keuken hadden gekeken, koos Chrysler ervoor om intensief samen te werken met leveranciers. Leveranciers werden beschouwd als onderdeel van de 'Extended Enterprise' en werden actief uitgenodigd om met suggesties te komen voor kostenbesparingen in de gehele keten. Dit was ongehoord in de auto industrie. Chrysler koos voor vertrouwen en loyaliteit als uitgangspunt. Dat betekende concreet dat zolang leveranciers hun targets haalden er niet werd geresourced. Als er zich problemen voordeden werd niet direct van leverancier gewisseld, wat op het eerste gezicht de makkelijkste optie lijkt, maar werd samen met de leverancier gekeken hoe de problemen opgelost konden worden (i.e. supplier development). Door de Extended Enterprise filosofie bleek Chrysler in staat om leveranciers te betrekken in productontwikkeling en om ze zelfs te laten investeren in nieuwe producten en processen. Omdat de relatie stabiel was, durfden leveranciers dat wel aan zonder harde garanties te vragen. Chrysler kon haar R\&D budget hierdoor zelfs verlagen (Stallkamp, 2005). Het is dus niet zo dat alleen Japanse bedrijven weten hoe ze effectief moeten samenwerken met leveranciers. 
Terecht zult u zich nu afvragen waarom ik Chrysler hier aanhaal als 'best practice' terwijl ze op dit moment bijna failliet zijn. Het antwoord zal blijken uit het volgende. In de auto-industrie wordt jaarlijks onderzoek gedaan naar de tevredenheid van de eerstelijns leveranciers over Working Relations met de grote zes: GM, Ford, Chrysler, Nissan, Toyota en Honda. Als we kijken naar de resultaten van dit jaarlijkse Working Relations Index (WRI) onderzoek dan valt op dat hoewel er schommelingen zijn waar te nemen Toyota en Honda sinds 2002 stabiel aan kop liggen met scores royaal boven het industrie gemiddelde (Henke, 2007). Opmerkelijk is het feit dat Chrysler na de succesvolle jaren 1992-1998, waarin Chrysler op gelijke hoogte stond met Toyota en Honda, sinds de fusie met Daimler-Benz een vrije val heeft gemaakt en nu helemaal onderaan de ranking staat. Stallkamp kwam binnen als de prins op het witte paard en kuste Chrysler wakker, maar het lijkt erop dat men daar weer in slaap is gevallen sinds Stallkamp is vertrokken direct na de fusie. De Duitse aanpak heeft Chrysler geen goed gedaan. Ze leefden hier dus niet lang en gelukkig.

Tabel 4 Overzicht van scores Working Relations Index 2002-2008

\begin{tabular}{|c|c|c|c|c|c|c|c|c|c|}
\hline \multirow{2}{*}{ OEM } & \multicolumn{7}{|c|}{ Year } & \multirow{2}{*}{$\begin{array}{c}2007- \\
2008 \\
\% \text { Change }\end{array}$} & \multirow{2}{*}{$\begin{array}{c}2006- \\
2008 \% \\
\text { Change }\end{array}$} \\
\hline & 2002 & 2003 & 2004 & 2005 & 2006 & 2007 & 2008 & & \\
\hline Toyota & 314 & 334 & 409 & 415 & 407 & 415 & 367 & $-11.6 \%$ & $-9.8 \%$ \\
\hline Honda & 297 & 316 & 384 & 375 & 368 & 380 & 359 & $-5.5 \%$ & $-2.4 \%$ \\
\hline Nissan & 227 & 259 & 302 & 298 & 300 & 289 & 253 & $-12.5 \%$ & $-15.7 \%$ \\
\hline $\begin{array}{l}\text { Industry } \\
\text { Mean }\end{array}$ & 224 & 234 & 266 & 259 & 266 & 270 & 249 & $-7.8 \%$ & $-6.4 \%$ \\
\hline Ford & 167 & 161 & 163 & 157 & 174 & 162 & 191 & $17.9 \%$ & $9.8 \%$ \\
\hline GM & 161 & 156 & 150 & 114 & 131 & 174 & 163 & $-6.3 \%$ & $24.4 \%$ \\
\hline Chrysler & 175 & 177 & 186 & 196 & 218 & 199 & 161 & $-19.1 \%$ & $-26.1 \%$ \\
\hline
\end{tabular}

The Working Relations Index (WRI) ranks OEMs' supplier working relations based on 17 criteria across five (5) areas: OEM-Supplier Relationship, OEM Communication, OEM Help, OEM Hindrance, and Supplier Profit Opportunity. WR. scores can range from zero to 500 , with 500 indicating the best supplier relations. A WRI ranking of zero to 249 indicates very poor to poor supplier working relations; 250-349 indicates adequate relations; and 350-500 indicates good to very good supplier working relations.

Bron: Hedge, 2008

Wat is nu het belang van een dergelijke WRI index? Een hoge WRI score geeft aan dat leveranciers de werkrelatie met de klant als positief ervaren. Henke (2007) geeft aan dat een hoge score bepalend is voor de manier waarop leveranciers schaarse resources willen delen met hun klanten. Resources moeten hier breed worden opgevat, het gaat om 
materialen en producten, maar ook om mensen, kapitaal, technologie en kennis. Enkele concrete voorbeelden:

- De leverancier deelt een uniek en innovatief idee als eerste met jou en niet met de concurrent

- De leverancier is bereid specifieke investeringen te doen en/of werkmethoden aan te passen voor jou en niet voor je concurrent

- Leverancier komt met suggesties voor kosten reductie, kwaliteitsverbetering, productontwikkeling, etcetera

- Leverancier levert in tijden van materiaal schaarste wel aan jou maar niet aan de concurrent in tijden van materiaal schaarste

Die klanten die consequent de voorkeur krijgen boven andere klanten worden tegenwoordig customers of choice genoemd (Bew, 2007). Een nieuwe term die steeds vaker klinkt in inkoopland. De Engelse versie van DEAL!, het blad 'Supply Management', heeft in 2008 een studie uitgevoerd waaruit naar voren kwam dat $72 \%$ van de respondenten denkt dat de customer of choice status belangrijker zal worden in de toekomst. IMD spreekt al van de 'the next game in purchasing'.

Ik ben gefascineerd door de vraag hoe je customer of choice kunt worden bij de beste leveranciers op de markt. Wat doen Toyota en Honda nu dat hun aanpak richting de world-class leveranciers zo effectief maakt? Hoe komt het dat zij customer of choice zijn en consequent voorkeur krijgen boven andere partijen in de markt als het gaat om toewijzen van schaarse resources? Wat is nu precies het verschil met bedrijven als $G M$, Ford en Chrysler? Ook deze laatste bedrijven investeren namelijk veel tijd en geld in professionele inkoop functies en het opbouwen van relaties met hun leveranciers.

Om het eerste misverstand maar direct weg te werken. Een groot aandeel in de omzet van de leverancier is niet voldoende voor het verkrijgen van een customer of choice. Veel omzet geeft een inkoper wellicht een keyaccount status, maar dit garandeert nog niet automatisch dat deze ook een voorkeursbehandeling krijgt. Onderzoek van de Corporate Executive Board (Bew, 2007) toont aan dat slechts $36 \%$ van de key accounts ook daadwerkelijk en consequent een voorkeursbehandeling krijgt. Er is dus meer nodig dan een alleen een mooie omzet, maar wat?

Michael Leenders (1988) zou zeggen wacht niet op de leverancier maar neem het initiatief en gebruik 'Reverse Marketing' technieken om de 
leverancier te verleiden om specifieke investeringen te gaan doen. Vanuit het denken in termen van verleiden is het niet zo verwonderlijk dat recent een aantal collega onderzoekers zich hebben gestort op het concept 'aantrekkelijkheid' (Hald et al, 2008, Bew, 2007; Cordon et al, 2008; Ellegaard et al, 2007; Christiansen et al, 2002). Deze studies tonen aan dat...

"Suppliers will not improve/adapt their processes, product technologies and participate in joint innovation projects with specific customers, unless... a minimum level of attraction...is present

Al weer tien jaar geleden viel mijn oog in een boekwinkel in Dublin op het boekje "Successful Purchasing in a week" van Stephen Carter (1998). Dit is een bijzonder aardig boekje dat de geïnteresseerde leek in een week probeert in te wijden in het inkoopvak. Voor iedere dag van de week staat een inkooponderwerp op de agenda. Bij woensdag aangekomen viel mijn oog op de volgende matrix (zie figuur 1). In de Marketing literatuur zijn diverse varianten van een dergelijke portfolio benadering te vinden, maar de benadering van Carter spreekt mij aan omdat deze expliciet toegepast wordt in een inkoopcontext.

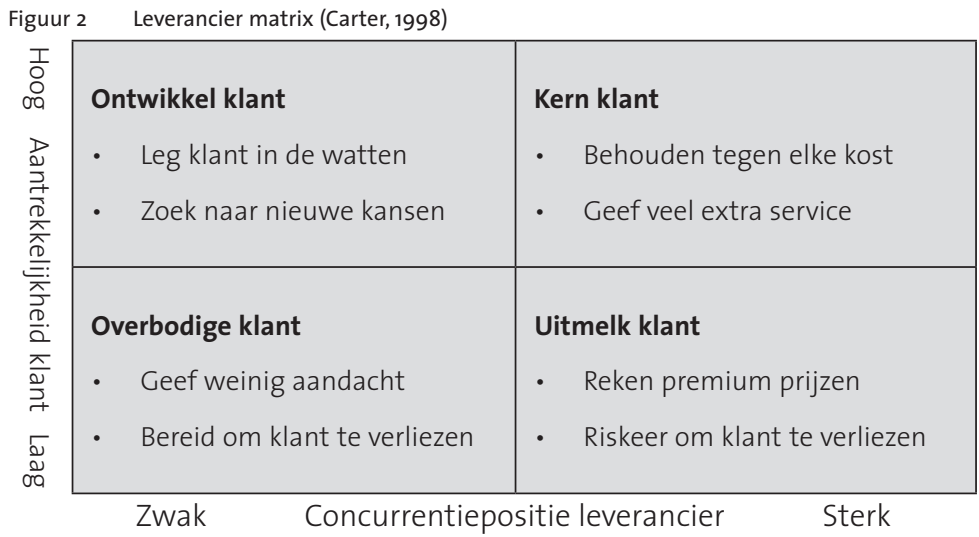

Volgens Carter (1998) zijn er voor leveranciers twee factoren die de positie van hun klanten bepalen: ten eerste de concurrentiepositie van de leverancier op de markt en ten tweede de aantrekkelijkheid van de klant. Als bijvoorbeeld een leverancier besluit dat een specifieke klant zeer aantrekkelijk is, maar de eigen positie op de markt is niet sterk, dan is sprake van een ontwikkel klant en zou de leverancier een strategie 
kunnen kiezen die gericht is op het in de watten leggen van die klant. Dit vraagt om het toewijzen van extra middelen aan deze specifieke klant om de business zeker te stellen en wellicht zelfs te laten groeien. Door te investeren in de klant hoopt de leverancier op zijn beurt weer 'supplier of choice' te worden. Het alternatief is dat de leverancier ervoor kiest om elders business op te bouwen omdat de huidige marktleiders een te sterke positie hebben en de kans bestaat dat de extra investeringen in de klant geen rendement opleveren.

Laten we eens nader bekijken wat Carter bedoelt met aantrekkelijkheid. Hij stelt dat leveranciers een klant aantrekkelijker zullen vinden naarmate er meer sprake is van:

- Winstgevendheid van de omzet

- Omzet groeipotentieel

- Leer potentieel (interessante kennis aanwezig bij klant die ingezet kan worden om nieuwe klanten te ontwikkelen)

- Correct betalingsgedrag

- Uitdagende klantvraag (bijvoorbeeld een speciale verpakking)

Hoewel 'aantrekkelijkheid' een rol lijkt te spelen bij succesvolle samenwerking met leveranciers en het op zich een aantrekkelijke construct is, ben ik van mening dat het een te generiek construct is. Het vertoont daarnaast ook grote overeenkomsten met andere constructen zoals bijvoorbeeld 'supplier satisfaction', waar aspecten als correct betalingsgedrag, winstgevendheid en dergelijke ook deel van uitmaken (Maunu, 2003, Van de Vijver, 2009). Identieke items gebruiken voor twee verschillende constructen is niet wenselijk. Laten we verder kijken.

In de vele workshops en trainingen die ik in de afgelopen 12 jaar heb mogen geven bij diverse bedrijven, onderwijsinstellingen en de NEVI, heb ik vaak de vraag gesteld aan de deelnemers: "wat kenmerkt nu je allerbeste leverancier?" Welke kenmerken zie je terug bij een echte partner? Veel genoemde kenmerken zijn:

- vertrouwen

- meedenken

- flexibiliteit

- pro-activiteit

- win-win

- openheid

- communicatie 
- wederzijdse belangen respecteren

- delen van risico's en opbrengsten

Mijn eerste observatie is dat inkoopmanagers heel goed weten wat ze graag zouden willen van leveranciers, de antwoorden komen snel en zijn vaak talrijk. In de opsomming hierboven laat ik slechts de meest genoemde kenmerken zien. Het blijkt dat slechts een klein percentage (o-3\%) van de leveranciers aan deze kenmerken voldoet. In dergelijke sessies vraag ik de deelnemers hoe zij als bedrijf zelf scoren op deze aspecten. Over het algemeen ontstaat er dan een wat lacherige sfeer, waarin wordt toegegeven dat die score niet al te best is. Dit is in lijn met de bevindingen van Cordon en Vollman (2008) die aangeven dat inkopende bedrijven sterk de neiging hebben om te denken dat ze goede klanten zijn, dat het makkelijk is om zaken met hen te doen en dat iedere leverancier van hen houdt. Deze vorm van bijziendheid verklaart voor mij ten dele het feit dat er nog zo weinig goede voorbeelden te vinden zijn van vruchtbare samenwerking met leveranciers. De wens om intensief samen te werken is vaak te eenzijdig, maar 'it takes two to tango'!

Ik ben ervan overtuigd dat de beste leveranciers op de markt in principe graag willen samenwerken met hun klanten en bereid zijn te investeren in de relatie, maar ze willen daar wel wat voor terugzien op korte of lange termijn. Met andere woorden de 'customer value' die zij leveren moet in verhouding zijn met de 'supplier value' die zij retour ontvangen (Ramsey et al, 2007). Dergelijke supplier value kan zitten in, specifieke kennis en informatie, early supplier involvement, supplier development, best supplier awards, etc.. Omdat niet altijd expliciet duidelijk is wat waardevol is voor een leverancier, pleiten Ramsey et al (2007) ervoor dat inkoopprofessionals meer aandacht zouden moeten besteden aan 'Organisational Supplying Behavior' waarbij systematisch gekeken wordt naar de motivaties, intenties en verlangens van leveranciers. Pas als inkoopprofessionals een goed begrip hebben wat leveranciers beweegt, weten ze wat hen te doen staat om de leveranciers te verleiden meer waarde te gaan leveren.

Tot nu heb ik in mijn betoog het vraagstuk rond customer of choice benaderd vanuit de praktijk gebruikmakend van enkele populaire publicaties (met enkel anekdotisch bewijs), congres papers en boeken. De conclusie is dat er vele meningen en hypothesen zijn ten aanzien van het onderwerp, maar nog maar weinig hard bewijs. Een meer fundamentele en toetsende benadering is gewenst. Hier in Maastricht 
bekijk ik samen met Agnes Blonska en Martin Wetzels dit vraagstuk op een fundamenteel theoretisch niveau. Na een diepgravende literatuur studie zijn diverse theorieën gevonden die toepasbaar zijn op het onderwerp. Denk hierbij aan Relationship Marketing theorie, Netwerk theorie, Social Capital theorie en de Social Exchange theorie. In de modellen van deze theorieën kunnen we diverse variabelen terugvinden die effect hebben op de mate warin een partij zich wil binden aan een andere partij. Met name vertrouwen lijkt bepalend te zijn voor de mate van samenwerking tussen inkoper en leverancier (Morgan \& Hunt, 1994). Vertrouwen is een lastig te definiëren concept, maar drukt in essentie de mate uit waarin de ene partner de andere partner ziet als eerlijk, integer en goedwillend (Morgan \& Hunt, 1994). Alvarez et.al. (2003), Lehtonen (2006) en Sengun et.al. (2007) tonen aan dat vertrouwen belangrijk is voor het aangaan van effectieve relaties met andere bedrijven, maar dat vertrouwen alleen niet genoeg is. Na vertrouwen wordt ook commitment veel genoemd. Dit drukt de intentie uit om met de desbetreffende partner te blijven samenwerken in de toekomst en komt tot uiting in de mate waarin men bereid is te investeren in elkaar. Naast vertrouwen en commitment wordt tenslotte ook tevredenheid vaak als bepalende variabele genoemd (Van de Vijver, 2009). Het gaat hier om de tevredenheid over de samenwerking zelf (bv. kwaliteit van de communicatie) en de resultaten (bv. winstgevendheid) die daaruit voortvloeien. Deze drie variabelen zijn afhankelijk van de ervaringen die beide partners met elkaar hebben gedurende de samenwerking en kunnen dus veranderen in de tijd. Ze vereisen dus continue monitoring. Daarom is het verstandig om, zoals IBM, Nokia, Atlas Copco, Ikea en Numico al doen, periodiek de belangrijkste leveranciers uit te nodigen om een formele beoordeling te geven over het gedrag van de klant. Door te luisteren naar de 'Voice of the supplier' leren deze bedrijven te kijken naar de eigen organisatie als ware het door de ogen van de leverancier, wat heel leerzaam kan zijn.

Het moge ondertussen duidelijk zijn dat je geen customer of choice wordt door simpelweg de supplier development aanpak van Toyota te imiteren. Je moet in staat zijn om een atmosfeer van vertrouwen, commitment en tevredenheid op te bouwen waarbinnen de relatie zich kan ontwikkelen. Dave Nelson, voormalig CPO van Honda of America, beschreef het als volgt: "We try to win their hearts". Vanwege de grote sociale component binnen samenwerking maken we in ons onderzoek gebruik van de Social Capital theorie. Deze theorie is beter geschikt 
dan bijvoorbeeld de Transactiekosten theorie voor het verklaren van gedrag in sociale structuren zoals inkoper-leverancier relatie (Uzzi, 1997). Social capital kan gezien worden als een unieke resource die is ingebed in de relatie die twee partijen hebben en die afhankelijk is van wat beide partijen investeren in de relatie. Naarmate er meer social capital aanwezig is, leidt dat tot meer rendement uit de relatie voor zowel inkoper als leverancier. De customer of choice status hebben wij vertaald in het theoretische construct 'structural embeddedness' dat een centraal onderdeel is van Social Capital. Wij onderzoeken momenteel onder welke voorwaarden supplier development tot 'structural embeddedness' kan leiden en welk voordeel dat vervolgens oplevert voor zowel inkoper als leverancier. Aan de hand van een uitgebreide web-survey meten we de percepties van leveranciers over de relatie die zij met hun klant hebben. We hebben 185 bruikbare leveranciers vragenlijsten verzameld binnen de context van één grote multinational. We meten naast supplier development en structural embeddedness ook zaken als tevredenheid, commitment, vertrouwen, participatie en de mate waarin de inkoper een voorkeursbehandeling krijgt van de leveranciers. De eerste publicatie verwachten we op korte termijn in te dienen bij een vooraanstaand journal. De volgende stap in het onderzoek zal een dyadische analyse zijn. We hebben namelijk de inkopers dezelfde vragenlijst voorgelegd en gevraagd naar hun mening over de leveranciers. Dit heeft geresulteerd in een dataset van 105 unieke paren. De eerste resultaten van dit onderzoek verwacht ik tweede helft van dit jaar te kunnen presenteren. 


\section{Deel V - Ontwikkelen van de inkoper}

Dames en heren,

Inkoop is mensenwerk. De effectiviteit van de inkoopfunctie wordt sterk bepaald door de inkoopprofessionals die daarbinnen werkzaam zijn (Carter et al 2000). De taakinhoud van inkopers heeft in de afgelopen decennia een grote verandering doorgemaakt. In de jaren tachtig werd de inkoper in personeelsadvertenties beschreven als een zelfstandige, prijsgerichte onderhandelaar. De inkoper van vandaag moet een allrounder, ondernemer, teamspeler, synergiezoeker en consultant zijn. Een andere taakinhoud betekent ook dat nieuwe kennis en vaardigheden noodzakelijk worden. De topperformers op gebied van inkoop realiseren zich dat mensen belangrijk zijn en besteden veel tijd aan het rekruteren en opleiden van de juiste mensen (Reinecke et al, 2007).

Het heeft mijn grote interesse om onderzoek te doen naar de mens achter de inkoopprofessional. Zonder de ambitie te hebben om compleet te zijn, wil ik u graag laten zien welke mogelijkheden er liggen voor interessant onderzoek. Sinds mijn aanstelling ben ik bezig met het verzamelen van onderzoek op dit onderwerp en in dit hoofdstuk wil ik graag enkele observaties met $u$ delen. Als eerste wil ik graag ingaan op de vraag: wat bepaald de effectiviteit van een inkoopprofessional? Om hier zicht op te krijgen heb ik een literatuurstudie uitgevoerd binnen de JPSM en JSCM. Dit leverde over de periode 1995-2008 diverse publicaties op die allen aandacht besteden aan factoren die de effectiviteit van een inkoopprofessional beïnvloeden. Er zijn onderzoekers die het antwoord vooral zoeken in de wat de inkoper moet doen (de taak) en welke kennis en vaardigheden noodzakelijk zijn om die taak goed uit te voeren (Guinipero et al 1999; 2000; Carr et al, 2000, Large, 2004; 2005; Trent, 1996:1998). Andere onderzoekers concentreren zich meer op de persoon achter de inkoper. Zij gaan bijvoorbeeld in op vragen als:

- wat motiveert de inkoper? (Pagell, 1996; Englyst et al, 2008),

- hoe gaat de inkoper om met conflicten? (Plank et.al., 2006),

- welke impact heeft job stress op de inkoper? (Michaels et.al., 1995),

- wat bepaalt job satisfaction van een inkoper? (Preis, 2003; Hallenbeck et al, 1999), 
- maakt het uit of de inkoper een man of een vrouw is? (Pullins et.al., 2004; Larson et.al., 2008).

Tenslotte zijn er onderzoekers die het antwoord zoeken in de omgeving waarin de inkoper werkt. Denk hierbij bijvoorbeeld aan het al dan niet aanwezig zijn van Human Resource Management, een Cultuur van samenwerken of Top management support (Carter et al, 2000; Faes et al 2001; Tassenbehji et al 2008).

Wat maakt een persoon geschikt om als inkoper te werken? Uit de literatuur wordt duidelijk dat daarvoor naar vier aspecten gekeken kan worden: vakkennis, vaardigheden, persoonlijkheid en uiterlijk. Laten we ieder van deze vier eens kort nader bekijken.

\section{Vakkennis}

Vakkennis kan worden gedefinieerd als het theoretische en/of praktische begrip van een bepaald onderwerp verkregen door praktijkervaring en/ of opleiding. In de meeste gevallen zal bij het aannemen van een inkoopprofessional gekeken worden naar de beschikbare inkoopkennis. De aanwezigheid van vakkennis hangt immers nauw samen met de job performance van inkopers (Ghingold et al, 1997). Voor de hoogste inkoopbazen (CPO) ligt dat anders, daar blijkt dat vakkennis niet per se een vereiste is gezien het grote aandeel CPO's zonder specifieke inkoop vakkennis dat wordt aangenomen (Johnson et al, 2009). Voor de CPO zijn algemene management vaardigheden belangrijker dan inkoop vakkennis. Giunipero et al (2004) stellen dat de inkoper van het jaar 2010 tenminste theoretisch en praktisch begrip moet hebben van de volgende onderwerpen:

1. Supplier Relationship Management

2. Total Cost Analysis

3. Purchasing strategies and plans

4. Analysis of suppliers

5. Competitive market analysis

Vakkennis alleen is niet genoeg. Als een inkoopprofessional niet de juiste vaardigheden bezit, zal deze niet effectief zijn.

\section{Vaardigheden}

Vaardigheid betreft het vermogen om vakkennis effectief in te kunnen zetten (bv. Met behulp van communicatieve vaardigheid). Binnen de 
inkoopdiscipline is Guinipero (1993; 1999; 2004; 2005; 2006) al sinds jaar en dag bezig met het verkrijgen van inzicht in welke vaardigheden inkoopprofessionals nodig hebben om hun functie goed uit te oefenen. Als je alle beschikbare studies op het gebied van inkoopvaardigheden naast elkaar legt, zoals een van mijn afstudeerders onlangs heeft gedaan (Balvers, 2009), dan blijkt dat meer dan 60\% van deze artikelen 'Communicatieve vaardigheden' benoemt als de belangrijkste vaardigheid voor inkoopprofessionals. Daarna komen de volgende vaardigheden (in volgorde van belangrijkheid):

- Samenwerken in teams

- Interpersoonlijke vaardigheden (i.e. luisteren, feedback geven)

- Strategisch denken

- Inkooptechnische vaardigheden

- Onderhandelen

Bijna alle inkoopprofessionals hebben te maken met een hoge mate van interactie met anderen. Om effectief te zijn in contact met anderen is in mijn visie ook een bepaalde persoonlijkheid gewenst.

\section{Persoonlijkheid}

"Een goede inkoper wordt geboren aan de goede kant van de straat en speelt in zijn jeugd regelmatig aan de verkeerde kant van de straat"

Deze stelling is van de helaas te vroeg overleden Ton van Zwam (voormalig inkoopdirecteur van ASML en NEVI bestuurder) en hij doelde hiermee op de persoonlijkheid van de inkoper. Een goede inkoper moet zowel in staat zijn met twee woorden te spreken als ook met de boeven van deze wereld (lees: de verkopers van de leverancier) weten om te gaan. Boeven vang je immers met boeven!

In de in-company trainingen die ik verzorg voor diverse grote ondernemingen blijkt keer op keer dat zolang we met inkoopprofessionals praten over inkoopkennis en technische vaardigheden het allemaal prima loopt. Echter, ze hebben vaak moeite om de kennis en vaardigheden om te zetten in daadwerkelijk effectief gedrag als ze aan een rollenspel mee moeten doen. In zo'n setting vallen veel inkopers terug op hun geloof in het eigen gelijk en proberen op basis van overtuigingskracht de ander te beïnvloeden. Maar gelijk hebben betekent nog niet altijd gelijk krijgen. Werkelijk contact maken met een interne klant of een leverancier vraagt van de inkoopprofessionals om los te komen van de eigen belangen en 
te zoeken naar een gezamenlijke positie. Erik de Bruine, CPO van de Rabobank, stelt dat de toegevoegde waarde van inkoop valt of staat met het focussen op de belangen van de interne klant, zowel rationeel en emotioneel (hij noemt dit 'klant alignment') (De Bruine, 2008). Het rationele stuk is voor de gemiddelde inkoper geen probleem, maar het emotionele stuk wel, zo is mijn ervaring in de trainingen. Het vraagt van inkopers dat ze in de huid kruipen van de interne klant, kunnen luisteren, durven door te vragen en empatisch vermogen ten toon kunnen spreiden. Het feit dat inkopers in de meeste gevallen meerdere interne klanten hebben die ieder hun eigen aanpak vereisen maakt het er niet gemakkelijker op. Reynolds (2004) is van mening dat inkoopprofessionals een hoge mate van Emotionele Intelligentie moeten bezitten en dus beschikken over de volgende kenmerken:

- Zelfkennis: in staat om de eigen emoties te herkennen en te managen

- Emotionele veerkracht: in staat om emotionele tegenslagen te verwerken

- Zelfmotivatie: drive en energie om resultaten te behalen

- Empathie: in staat om emoties \& behoeften van anderen te herkennen

- Overtuigingskracht: in staat om anderen over te halen hun oordeel en/of mening te veranderen

- Intuïtie: in staat om de intuïtie aan te spreken in complexe situaties

Uit onderzoek onder 81 Engelse inkoopmanagers bleek dat inkoopmanagers gemiddeld hoger scoorden dan collega managers uit andere functiegebieden op de elementen Overtuigingskracht, Emotionele veerkracht en Zelfmotivatie (Reynolds, 2004). Dit betekent dus dat inkoopmanagers relatief gezien niet beter scoren op de kenmerken Zelfkennis, Empathie en Intuïtie. Helaas geeft het onderzoek van Reynolds (2004) geen valide verklaring voor deze resultaten. Naar mijn mening een mooi onderwerp voor 'further research'.

Een aantal Nederlandse bedrijven (o.a. NS, Rabobank) werkt al met gedragstesten en sessies met gedragstherapeuten om deze ' $X$ factor' te achterhalen bij hun inkoopprofessionals. Enerzijds om te kunnen beoordelen of ze de juiste persoon op de juiste plek zijn en anderzijds om na te gaan op welke punten er noodzaak is aan een stuk persoonlijke ontwikkeling. Naar mijn mening zal er alleen nog maar meer aandacht komen voor persoonlijkheidskenmerken binnen inkoop. Er wordt al 
voorspeld dat binnen vijf jaar zelfs hersenscans zullen worden ingezet om de persoonlijkheid van sollicitanten bloot te gaan leggen (Oosting, 2009).

\section{Uiterlijke kenmerken}

Fysieke kenmerken kunnen direct effect hebben op de effectiviteit van een inkoper. Wood et al (2008) hebben aangetoond dat een aantal uiterlijke kenmerken van verkopers zeer bepalend is voor het opbouwen van vertrouwen bij klanten. De onderzochte kenmerken waren:

a) kledingkeuze,

b) vriendelijke uitstraling van het gezicht,

c) haardracht,

d) overgewicht.

Op overgewicht na, bleken alle factoren positief gerelateerd aan de mate waarin verkopers in staat waren vertrouwen op te bouwen en daarmee dus ook hun verkoopresultaat te verbeteren. Uiterlijk en uitstraling spelen dus een rol bij het presteren van verkopers. De kans is naar mijn mening vrij groot dat dit ook zo zal zijn bij inkopers. Wat weten we over het uiterlijk van inkopers? Het stereotype beeld dat nog bij veel mensen leeft is dat van een man (dus geen vrouw!), van middelbare leeftijd (dus niet jong!), die een kobaltblauw colbert draagt met weinig pasvorm in combinatie met een Mickey Mouse stropdas, witte sokken en bruine schoenen. Niet bepaald de prins op het witte paard. De realiteit is echter dat er tegenwoordig veel jonge goedgeklede professionals in inkoopland zijn te vinden. Snijders en Tazelaar (2009) vinden op basis van experimenten dat mensen zich in vertrouwenssituaties laten leiden door het uiterlijk van de ander. Hoe betrouwbaarder men iemand eruit vind zien, hoe sneller men diegene vertrouwt. Waarbij het overigens zo is dat er geen enkel verband blijkt te zijn tussen de ingeschatte betrouwbaarheid en de werkelijke betrouwbaarheid van die andere persoon.

Enige tijd geleden was in The Wall Street Journal te lezen dat verkopers liever geen vermoeide uitdrukking op hun gezicht willen hebben bij een eerste contact met een nieuwe klant. "Als je er krachtig en gezond uitziet krijg je meer respect en dat is goed voor de business", aldus een verkoper. Daarom laat een groeiend aantal Amerikaanse verkopers hun gezicht botoxen (Hwang, 2002). Ver van ons bed? Het Financieel Dagblad deed onlangs verslag van een nieuwe kliniek in het Gooi waar 
zakenmensen hun gezicht laten botoxen om maar niet de indruk te wekken dat ze slapenloze nachten hebben of gestrest zijn (De Jongh, 2009). De teneur is ook hier weer: ik moet er goed uitzien, want mijn klanten moeten vertrouwen hebben in mij en mijn bedrijf. Hoe zou het zijn met de inkoopprofessionals? Zouden botox en facelifts al een rol spelen? Zijn inkopers zich bewust van het effect dat kleding, haardracht en uitstraling kunnen hebben bij contacten met verkopers en interne klanten? Ik ben er wel benieuwd naar.

\section{Human Resource Development: nature or nurture?}

Carr en Smeltzer (2000) stellen dat veel bedrijven de overtuiging hebben dat als een persoon de juiste persoon lijkheid heeft en de potentie om de kennis en technische vaardigheden te leren, deze persoon succesvol zal zijn. Of zoals Bert-Ove Johansson (voormalig CPO van Skanska) het stelt: "I recruit attitude and I train skills". Dit verklaart dat veel bedrijven hun nieuwe inkopers trainingen aanbieden op gebied van inkooptechnische vaardigheden. Hoewel er een groeiend aantal publicaties beschikbaar is dat beschrijft in welke richting inkoopkennis en -vaardigheden moeten veranderen is er nog maar weinig wetenschappelijk onderzoek gedaan naar hoe die kennis en vaardigheden ontwikkeld moeten worden binnen inkooporganisaties.

Bij het transformeren van de inkoopfunctie naar een strategische functie speelt executive education een cruciale rol, aldus Freeman en Cavinato (1992). Training is dus belangrijk, maar er is meer nodig. Naast training is een compensatie systeem en een prestatie meetsysteem nodig om de inkopers te motiveren nieuwe kennis te adopteren en te gebruiken in hun dagelijkse werk (Pagell, 1996). Maar dan zijn we er nog niet, volgens McKinsey. Zij stellen dat je naast stevig investeren in recruitment, training, job rotation, management development program ma's en beloningssystemen ook tenminste de helft van je huidige inkoopmanagers zult moeten vervangen (Keough, 1994; Chapman et al, 1997; Reinecke et al, 2007).

Het is naar mijn mening interessant en relevant om nader te bekijken of de genoemde Human Resouces Development (HRD) instrumenten ook werkelijk effectief zijn. Daarom heb ik samen met een van mijn afstudeerders een onderzoek opgestart op dit thema (Rüdiger, 2009). Uiteindelijk willen we onderzoeken of er een relatie bestaat tussen gebruikte HRD instrumenten, de beschikbare inkoopprofielen 
(kennis, vaardigheden, gedrag en uiterlijk) en de uiteindelijke inkoopperformance.

Tabel 5 Overzicht van de constructen (Rüdiger, 2009

$\begin{array}{lll}\text { HRD instrumenten } & \text { Inkoopprofielen } & \text { Inkoopperformance } \\ \text { • Recruitment } & \text { • Kennis } & \text { - Significante } \\ \text { - Training } & \text { - Vaardigheden } & \text { kostenbesparingen } \\ \text { - Coaching/mentoring } & \text { •Persoonlijkheid } & \text { - Professionaliteit } \\ \text { - Performance } & \text { - Uiterlijk } & \text { inkoopfunctie } \\ \text { appraisal } & & \text { - Invloed inkoopfunctie } \\ \text { - Personal development } & \text { - Effectiviteit inkoop } \\ \text { plans } & \text { professionals } \\ \text { - Compensation } & \\ \text { - Job rotation } & \end{array}$

We hebben een uitnodiging voor een web-survey verstuurd via de NEVI nieuwsbrief waarop uiteindelijk 87 NEVI leden gehoor hebben gegeven. Enkele voorlopige conclusies uit het onderzoek wil ik graag met u delen.

Wat kunnen we op dit moment zeggen over de inkoopprofessionals in Nederland? Met de vakkennis zit het wel goed (scores >3,5). Vaardigheden scoren minder hoog. Op onderhandelen na (score >3,7) scoren de items onder de 3,5, met uitschieters onder de 3 voor Strategische planning en Financiële vaardigheden. De meeste items met betrekking op persoonlijkheid scoren iets hoger dan 3,5. We hebben gemiddeld genomen te maken met doelgerichte en initiatiefrijke inkoopprofessionals, ze zijn echter minder sensitief voor de emoties van een ander en hebben moeite om de aan hen toegekende taken binnen de daarvoor gestelde termijn af te ronden (score iets meer dan 3). Wat betreft het uiterlijk is het beeld dat inkoopprofessionals gemiddeld genomen een vriendelijke uitstraling hebben $(>3,5)$, terwijl de scores voor kleding, kapsel en de fysieke verschijning iets lager liggen (iets meer dan 3).

Het onderzoek bevestigt, om het zwak uit te drukken, dat de relatie met HR functie nog voor verbetering vatbaar is. Er is nog maar weinig samenwerking met de HR professionals en er zijn nog maar weinig inkoopafdelingen die ook echt een HR professional in dienst hebben. Ook als we kijken naar de HR instrumenten die ingezet worden dan blijft dat 
eigenlijk beperkt tot training (score $>3,7$ ) en job interviews (score 4,5). $H R$ instrumenten zoals assessment centers, coaching \& mentoring, MD programma, job rotation worden nog maar spaarzaam ingezet (scores <3). Mijn advies aan de Nederlandse inkoopdirecteuren is om toch vooral eens te overwegen meer te investeren in HRM, want de cijfers tonen aan dat investeren in HRM een direct en positief effect heeft op de performance van inkoop (Rüdiger, 2009). 


\section{VI - Conclusies}

$U$ hebt, hoop ik, nu een idee gekregen van de onderzoeksvragen en thema's die mij binnen het inkoopdomein interesseren.

Mijn focus qua onderzoek ligt de komende jaren in eerste instantie op samenwerking tussen inkoper en leverancier en meer specifiek op de vraag hoe je tot unieke waardetoevoegende samenwerkingsrelaties kunt komen. Het onderzoek zal daarbij dyadisch van opzet zijn en met name toetsend van aard zijn. Daarnaast zal ik me bezig houden met het verder ontwikkelen van onderzoek op gebied van de menselijke factor in inkoop. Een eerste aanzet hiertoe vormt het onderzoek op het thema HRM in inkoop dat ik hierboven aanhaalde. Tenslotte, zal ik me blijven inzetten op het thema ontwikkelen en organiseren van concern inkoopfuncties, er is nog veel te onderzoeken op dat vlak.

Ik ben blij dat 'Purchasing Management' een vaste plek heeft in de Master Supply Chain Management in Maastricht. In het onderwijs zal ik me met enthousiasme inspannen om studenten passie en interesse mee te geven voor het inkoopvak. Enerzijds door de klassieke en actuele theorie op gebied van inkoop en leveranciersmanagement te introduceren en anderzijds door de praktijk in huis te halen in de vorm van gastsprekers, cases en projecten. Het ligt in mijn ambitie om ook de afstudeerprojecten van de studenten steeds meer af te stemmen op de onderzoek thema's van de leerstoel.

$\cup$ zult zich wellicht al een tijdje afvragen wie kust Doornroosje nou wakker? En als ze wakker wordt, leeft zij dan lang en gelukkig samen met de prins?

Wat dacht $u$ van de volgende variant? Er gingen 100 jaren voorbij. Toen kwam er een mooie en moedige jonge hoogleraar naar het hoofdkantoor van Sleeping Beauty BV. Met zijn academische zwaard baande hij zich een weg door de spreekwoordelijke doornhaag en binnengekomen vond hij de slapende CPO. Hij zag haar schoonheid, kuste haar en de CPO ontwaakte en met haar iedereen in het hoofdkantoor. De CPO werd vanzelfsprekend direct verliefd op de mooie jonge hoogleraar, ze trouwden en leefden nog lang en gelukkig. Maar helaas sprookjes bestaan niet, dus deze variant 
zal geen werkelijkheid worden. Hoogleraren kunnen zeker een rol spelen bij het ontwaken van bedrijven op gebied van inkoop, maar hun bijdrage is vaak indirect. Door onderzoek te doen en daarover te publiceren kunnen zij een bijdrage leveren aan het bewustwordingsproces bij de prins dat hij in actie moet komen.

Wie is dan de prins op het witte paard? Johnson en Leenders (2008) tonen op basis van een groot aantal cases aan dat de CEO vaak de eerste stap zet in het ontwaakproces door de beslissing te nemen te gaan investeren in de inkoopfunctie. Hun onderzoek toont verder aan dat consultants hierbij een belangrijke rol spelen. In vele gevallen zijn zij het die de CEO's influisteren om inkoop op de agenda te zetten. De hoogleraren, de consultants en de CEO's kunnen dus ieder op hun eigen manier bijdragen aan het ontwaken van de inkoopfunctie. Maar, om werkelijk door te groeien richting fase 4, 5 en 6 uit het inkoop ontwikkelmodel zullen de CPO en de inkoopprofessionals klaarwakker moeten zijn en tevens zelf de verantwoordelijkheid moeten nemen om dat ook te blijven. Dat vraagt naar mijn mening bereidheid om te leren en om kritisch te reflecteren op het eigen functioneren. Met andere woorden, het is wenselijk dat CPO's en inkoopprofessionals regelmatig in de spiegel kijken en indien nodig zichzelf wakker (laten) kussen.

En dan, leven ze nog lang en gelukkig? Ik ga ervan uit dat we over gelukkig spreken als de inkoopprofessionals met veel plezier naar hun werk gaan, als andere vakdisciplines en ook het management nauw betrokken zijn bij de inkoopfunctie, als leveranciers tevreden zijn met de samenwerking en daar waar mogelijk hun waarde kunnen toevoegen en dat de inkoopfunctie flink bijdraagt aan het realiseren van de ondernemingsdoelstellingen. Wat mij echter opvalt is dat in inkoopland perioden van geluk vaak maar kort duren. De inkoopfunctie staat erom bekend dat ze na een periode van voorspoed weer makkelijk in slaap valt (zie voorbeeld van Chrysler). Het is een veeleisende beauty. Zodra de aandacht van het topmanagement of de inkoopprofessionals verslapt is de kans groot dat ze weer in slaap valt. Keer op keer zal deze beauty dus wakker gekust moeten worden. Hiervoor zijn naar mijn mening vele prinsen nodig. Mijn oproep aan u is dan ook om Doornroosje wakker te kussen zodra $u$ haar slapend tegenkomt. Wacht $u$ daarmee niet te lang. Er is nog zoveel moois te beleven in inkoopland. 


\section{Dankwoord}

Dat ik hier vandaag sta heb ik mede te danken aan vele mensen. Ik ben dankbaar en vereerd dat een groot deel daarvan de moeite heeft genomen om hier vandaag aanwezig. Velen van u komen uit de Randstad en dat is een flink eind rijden hier vandaan en de A2 op vrijdag middag is bepaald geen pretje, zo weet ik uit ervaring. Dus nogmaals dank dat $u$ hier bent. Er zijn een aantal personen die ik hier graag wil bedanken.

Als eerste wil ik de NEVI en in het bijzonder de NEVI Research Stichting (NRS) bedanken voor het mogelijk maken van de NEVI leerstoel Purchasing and Supply Management hier in Maastricht. In het bijzonder wil ik Arno de Schepper, voormalig voorzitter van de NRS, bedanken. Arno, al weer zeven jaar geleden zaten we, onder geheel andere omstandigheden, samen in jouw mooie tuin in Waalre. Op dat moment kon in niet bedenken dat ik hier nog eens zou staan. Jij wel. Dank voor je vertrouwen. Natuurlijk wil ik ook Sicco Santema, de huidige voorzitter van de NRS, samen met NRS leden Philip van Beek en Constant Botter bedanken voor hun support en actieve betrokkenheid bij deze leerstoel.

Hier in Maastricht gaat mijn dank allereerst uit naar Ko de Ruyter, voorzitter van de vakgroep Marketing \& Supply Chain Management waar de leerstoel is ondergebracht. Ko, je zit op dit moment in Australië, maar bedankt voor je vertrouwen en je raad en daad. Daarnaast mag ook Jos Lemmink, decaan van onze faculteit, niet onvermeld blijven. Jos, dank voor al je bestuurlijke inspanningen om deze leerstoel mogelijk te maken.

Binnen de vakgroep gaat mijn dank in eerste plaats uit naar Piet Pauwels voor zijn advies en hulp bij het opzetten van het vak Purchasing Management, al weer 4 jaar geleden. Secondly, Agnes, you have the honour to be the first PhD researcher of this NEVI chair. Thanks to your 'pittbull' qualities you realized an impressive response rate on your survey and through that you layed the foundation for a promising PhD thesis. Many thanks for your good work and your delicious homemade Polish cakes and chocolates! Collega Martin Wetzels, Martin, dank voor je rol als co-promotor van Agnes, het meedenken en adviseren inzake de statistische methodologie en voor de prettige samenwerking in het Supply Chain Management onderwijs. Tenslotte wil ik alle andere 
collega's binnen de vakgroep en niet in de laatste plaats Nicole en Pascalle bedanken voor de plezierige samenwerking en ondersteuning.

Het beeld van een eenzame professor die alleen in zijn werkkamer zit en het ene na het andere artikel produceert is een romantisch beeld en geheel uit de tijd. Wetenschap is (inter)nationaal teamwork geworden. Ik wil in het bijzonder Björn Axelsson (Stockholm Business School) en Wendy van der Valk (TU Eindhoven) danken voor de prettige samenwerking bij diverse publicaties. Daarnaast put ik veel genoegen uit de WION bijkomst die ieder jaar in januari alle inkooponderzoekers in Nederland bij elkaar brengt in het mooie plaatsje Lunteren. Twee collega inkooponderzoekers wil ik in het bijzonder aandacht geven: Arjan van Weele (TU Eindhoven) en Finn Wynstra (RSM Erasmus University. Waar Arjan mijn professionele vader is, daar is Finn mijn professionele broer. Heren, ik haal heel veel inspiratie en lol uit de samenwerking met jullie en hoop dat deze nog lang mag duren. Ik ben nog op zoek naar professionele moeder...wellicht komt die ook nog een keer.

Er zijn een aantal bedrijven die al vanaf de start van deze leerstoel zeer actief hebben bijgedragen aan zowel onderwijs als onderzoek. Een aantal van hen wil ik expliciet noemen: Willem van Oppen (KPN), Ton Trommelen (DSM), Erik de Bruine (Rabobank) en last but not least Paul Masschelein (Atlas Copco). Zeer bedankt voor jullie betrokkenheid en inzet, want zonder inkooppraktijk is er geen inkooptheorie!

Mijn collega partners bij Solvint, Manu, Kris en Filip, mogen niet onvermeld blijven. Ik ben blij dat jullie het uit weten te houden met deze Hollander en mij mijn tijd gunnen voor de wetenschap.

Aad en Lida, ik wil jullie danken voor jullie onvoorwaardelijke steun en alle mogelijkheden die jullie mij hebben geboden om me te ontwikkelen en mijn ambities na te jagen. Ik prijs me gelukkig met twee van zulke fantastische ouders.

Marcia, jij weet als geen ander dat ik zonder jou onvoorwaardelijke steun hier zeker niet zou hebben gestaan. We zitten samen in het spitsuur van het leven en de afgelopen maanden waren nog intensiever, maar desondanks geef je me alle ruimte om te doen wat ik wil doen. Bedankt! 
Selma en Fenna, jullie waren erg enthousiast over deze dag en dan niet om de inhoud, maar vooral om het feit dat ik hier in een rode jurk rondloop. Jullie zijn mijn grote voorbeelden als het gaat om oneindige nieuwsgierigheid en leergierigheid. Op naar de limonade!

Ik heb gezegd. 


\section{Referenties}

Alvarez, S.A., Barney, J.B. and Bosse, D.A. (2003) Trust and its alternatives', Human Resouce Management, Vol. 42, Issue 4, pp. 393-404.

Andriesse, F. (2008) Interview met Marc Hermans, CPO van Barco, DEAL!, pp 14-17.

Ammer, D.S. (1974) 'Is your purchasing department a good buy?' Harvard Business Review, Issue March-April, pp. 36-59.

Balvers, M. (2009) 'The new purchasing professional', Master thesis (forthcoming) University of Maastricht.

Bettelheim, B. (1993) 'Het nut van sprookjes', Servire Uitgevers, Cothen

Bew, R. (2007) 'The new customer of choice imperative', Proceedings Annual ISM Conference, Session code BB, May 7, Las Vegas.

Bruine, E. de (2008) 'Succes heb je niet, success maak je samen', presentatie CPO of the year dag, 30 Oktober 2008, Bussum.

Butler jr., J.K. (1999) Trust expectations, informationsharing, climate of trust and negotiation effectiveness and efficiency', Group Organization Management, Vol. 24, pp. 217-

CAPS Research (2007)'Succeeding in a dynamic world: SupplyManagement in the decade ahead', ISM and Arizona State University.

Carr, A.S. and Smeltzer, L.R. (2000) 'An emperical study of the relationships among purchasing skills and strategic purchasing, financial performance and supplier responsiveness', Journal of Supply Chain Management, Vol. 36, Issue 3, pp. 40-54.

Carter, S. (1998) 'Successful Purchasing in a week', Institute of Management Foundation, Hodder \& Stoughton, Londen.

Carter, J.R., Smeltzer, L.R. and Narasimhan, R. (2000) 'Human Resource Management within purchasing management: its relationship to total quality management succes', Journal of Supply Chain Management, Vol. 36, Issue 2, pp. 52-62.

Carter, Ph.L., Carter, J.R., Monczka, R.M., Slaight, T.H. and Swan, A.J. (2000) 'The future of purchasing and supply: a ten-year forecast' The Journal of Supply Chain Management, Winter issue, pp. 14-26.

Chapman, T.L., Dempsey, J.J. Ramsdell, G. And Reopel, M.R. (1997) 'No time for lone rangers', McKinsey Quarterly, Issue 2, pp. 31-40.

Chen, I.J., Paulraj, A. \& Lado, A.A. (2004) Strategic purchasing, supply management and firm performance, Journal of Operations Management, Vol. 22, pp 505-523. 
Christiansen, P.E. and Maltz, A. (2002) 'Becoming and 'interesting' customer: procurement strategies for buyers without leverage', International Journal of Logistics: Research and Applications, Vol. 5, Issue 2, pp. 177-195.

Cordon, C \& Vollman, Th.E. (2008) The Power of Two, Palgrave McMillan, New York.

Dawson, Ch. (2005) 'A China price for Toyota', Business Week, February 21. Denton, J.C., Prien, E.P. (1963) 'Defining the perceived functions of purchasing personnel, Journal of Applied Psychology, Vol. 47, Issue 5, pp. 332-338.

Dyer, J.H. (1996) 'How Chrysler created and American Keiretsu', Harvard Business Review, Issue: July-August, pp. 42-56.

Ellegaard, Ch. and Ritter, Th. (2007). "Attractiveness in business markets: Conceptualization and propositions", 23rd Annual IMP Conference, Manchester, UK

Englyst, L.Jorgensen, F.Johansen, J. and Mikkelsen, O.S. (2008) 'Commodity team motivation and performance', Journal of Purchasing \& Supply Management, Issue 14, pp. 15-27.

Farmer, D. (1997) 'Purchasing myopia revisited', European Journal of Purchasing \& Supply Management, Vol. 1, Issue 3, pp. 1-8.

Faes, W. Knight, L. and Matthyssens, P. (2001) 'Buyer profiles: an emperical investigation of changing organizational requirements', European Journal of Purchasing \& Supply Management, Vol. 7, pp. 197-208.

Freeman, V.T. and Cavinato, J.L (1992) 'Fostering strategic change in a function through executive education: the case of purchasing', Journal of Management Development, Vol. 11, No 6, pp. 25-30.

Ghingold, M. and Johnson, B. (1997) 'Technical knowledge as value added in business markets: implications for Procurement and Marketing', Industrial Marekting Management, Vol. 26, Issue 3, pp. 271-280.

Giunipero, L.C. and Kolchin, M.G. (1993) Purchasing education and training, requirements and resources, Caps Research Report.

Giunipero, L.C., Dawley, D. and Anthony, W.P. (1999) 'The impact of tacit knowledge on purchasing decisions', Journal of Supply Chain Management, Vol. 35, Issue 1, pp. 42-49.

Giunipero, L.C. and pearcy, D.H. (2000) 'World-class purchasing skills: an emperical investigation', Journal of Supply Chain Management, Vol. 36, Issue 4, pp. 4-13.

Giunipero, L. \& Handfield R.B. (2004) Purchasing education and training II, CAPS Research Report, 
Giunipero, L.C., Denslow, D. and Eltantaw, R. (2005) Purchasing/supply chain management flexibility: moving to an entrepreneurial skill set', Industrial Marketing Management, Vol. 34, pp. 602-613.

Giunipero, L.C., Handfield, R.B. and Eltantaw, R. (2006) 'Supply Management's evolution: key skill sets for the supply manager of the future', International Journal of Operations \& Production Management, Vol. 26, Issue 7, pp. 822-844.

Hald, K.S., Cordon, C., Vollman, T.E. (2008) 'Towards an understanding of attraction in buyer-supplier relationships', Industrial Marketing Management,

Hallenbeck, G.S., Hautaluoma, J.E. and Bates, S.C. (1999) 'The benefits of multiple boundary spanning roles in purchasing', Journal of Supply Chain Management, Vol. 35, Issue 2, pp. 38-43.

Hardt, Ch.W., Reinecke, N. And Spiller, P. (2007) 'Inventing the 21st-century purchasing organization', McKinsey Quarterly, Issue 4, pp. 115-124.

Harink, J.H.A. (2005) 'Purchasing must become strategic...maar is het dan nog wel inkoop?, Oratie, Vrije Universiteit Amsterdam.

Hedge, M. and Henke jr, J.W. (2008) Annual Supplier Rankings of Automakers by Suppliers Shows Toyota and Nissan Slipping, Ford Gaining and Chrysler Tanking, Planning Perspectives, Press Release August 11, 2008.

Henke jr,J.W. (2007) 'How your supplier relations measure up', Procurement Leaders, Edition 9, April 2007.

Henke, J. and Martin, W. (1998) 'Developing a procurement training program', Journal of Purchasing and Materials Management, Vol. 25, Issue 2, pp. 26-35.

Humphrey, R.H. and Ashforth, B.E. (2000) Buyer-supplier alliances in the automobile industry: how exit-voice strategies influence interpersonal relationships', Journal of Organizational Behavior, Vol. 21, Issue 6, pp. 713-730.

Hwang, S.L. (2002) 'Some type A staffers dress for success with a shot of botox', The Wall Street Journal, July 31, 2002

Jackson, R.W. (1990) 'How multidimensional is the purchasing job?', Journal of Purchasing and Materials management, Vol. 26, Issue 4, pp. Johnson, P.F., Leenders, M.R., (2008) 'Changes in supply leadership', Journal of Purchasing and Supply Management, doi:10.1016/j. pursup.2008.10.002.

Jongh, de (2009) Het Financiële Dagblad, p. 12. 
Karakowski, L. and Miller, D.L. (2006) Negotiator style and influence in multi-party negotiatins: exploring the role of gender', Leadership \& Organization Development Journal, Vol. 27, Issue 1, pp. 50-65.

Keaveney, S.M. (1995) 'Working smarter: the effects of motivational orientations on purchasing task selection and retail buyer performance', Journal of business and psychology, Vol. 9, Issue 3, pp. 253-271.

Kerkhof, G. (2005) 'The Bermuda Triangle of Business Procurement: how to exploit dormant potential', Wiley-VCH, Weinheim

Kraljic, P. (1983) 'Purchasing must become Supply Management' Harvard Business Review, Issue of sept-oct, pp. 109-117.

Large, R.O. (2005) 'Communication capability and attitudes toward external communication of purchasing managers in Germany', International Journal of Physical Distribution \& Logistics Management, Vol. 35, Issue 6, pp. 426-444.

Large, R.O. and Gimenez, C. (2004) 'Oral communication capabilities of purchasing managers: measurement and typology', Journal of Supply Chain Management, Spring issue, pp. 17-32.

Large, R.O. (2005) 'External communication behaviour of purchasers effects on supplier management performance', Journal of Purchasing \& Supply Management, Issue 11, pp. 28-41.

Larson, P.D and Morris, M. (2008) 'Sex and salary: a survey of purchasing and supply professionals', Journal of Purchasing and Supply Management, Issue 14, pp. 112-124.

Leenders, M.R. and Blenkhorn, D.L. (1988) 'Reverse Marketing: the new buyer-supplier relationship', The Free Press

Lehtonen, T. (2006) 'Collaborative relationships in facility services', Leadership \& Organization Development Journal, Vol. 27, Issue 6 pp. 429-444.

Liker, J. and Choi, T. (2004) 'Building deep supplier relationships', Harvard Business Review, Vol. 82, Issue 12, pp. 104-113.

Maunu, S. (2003), 'Supplier Satisfaction: the Concept and a Measurement System', PhD thesis, University of Oulu

Michaels, R.E., Kumar, A. and Samu, S. (1995) 'Activity-specific role stress in purchasing', International Journal of Purchasing and Materials Management, Vol. 31, Issue 1, pp. 11-19.

Morgan, R.M. and Hunt, S.D. (1994), "The commitment-trust theory of relationship marketing", Journal of Marketing, Vol. 58 No. 3, July, pp. 20-38. 
Mulder, M. Wesselink, R. and Bruijstens, H.Chr. (2005) 'Job profile research for the purchasing profession' International Journal of Training and Development, Vol. 9, Issue 3, pp. 185-204..

Nooteboom, B. (1996) 'De opkomst van inkoop', ESB, 81e jaargang, nr. 4050, pp. 260.

Nordin, F. (2006) 'Outsourcing services in turbulent contexts: lessons from a multinational system provider', Leadership \& Organization Development Journal, Vol. 27, Issue 4, pp. 296-315.

Oosting, A. (2009) 'Hersenscan sollicitant is straks vanzelfsprekend', Algemeen Dagblad, 24 februari, 2009.

Pagell, M. Das, A, Curkovic, S. and Easton, L. (1996) 'Motivating the purchasing professional', International Journal of Purchasing and Materials Management, Summer issue, pp. 27-34.

Plank, R.E., Newell, S.J. and reid, D.A. (2006) Organizational buyers and conflict: the impact of conflict on ongoing and new purchasing situations', Journal of Purchasing \& Supply Management, Vol. 12, pp. 2-13.

Hamel, G. and Prahalad, C.K. (1990) 'The core competence of the corporation', Harvard Business Review, May-June.

Preis, M.W. (2003) 'The impact of interpersonal satisfaction on repurchase decisions', Journal of Supply Chain Management, Vol. 39, Issue 3, pp. 30-38.

Pullins, E.B, Reid, D.A. and Plank, R.E. (2004) 'Gender issues in buyer-seller relationships: does gender matter in purchasing?', Journal of Supply Chain Management, Vol. 40, Issue 3, pp. 40-48.

Purcell, K and Purcell, J. (1998) 'In-sourcing, Outsourcing and the growth of contingent labour as evidence of flexible empoyment strategies', European Journal of work and organizational Psychology, Vol. 7, Issue 1, pp. 39-59.

Ramsey, J. (2001) 'Purchasing's strategic irrelevance', European Journal of Purchasing and Supply Management, Vol. 7, Issue 4, pp. 257-263.

Ramsey, J. \& Wagner, B., (2007) 'Organisational supplying behavior: optimising purchasing performance', Proceedings Annual IPSERA Conference 2007, Bath (UK).

Ramsey, J. and Croom, S. (2008) 'The impact of evolutionary and developmental metaphors on Purchasing and Supply Management: a critique', Journal of Purchasing and Supply Management, Vol. 14, Issue 3, pp.. 
Reck, R.F. and Long, B.G. (1984) Purchasing: a competitive weapon, Journal of Purchasing and Materials Management, Fall, pp 2-8.

Reijniers, J.J.A.M. (2006) Luctor et emergo: het ontworstel process binnen inkoop, Inaugurele rede, 15 mei 2006, Nyenrode Business Universiteit.

Reinecke, N., Spiller, P. And Ungerman, D. (2007) 'The talent factor in purchasing', McKinsey Quarterly, Issue 1, pp. 6-9.

Reynolds, A. (2003) 'Emotional intelligence and negotiation', Tommo Press, Hampshire

Ribbers, P.M.A. (1980) 'Planning en Organisatie van de Inkoopfunctie in de Industriele Onderneming', proefschrift, Tilburg.

Rozemeijer, (1994) 'Managen van uitbestedingsrelaties: van noodzaak naar toegevoegde waarde', GTI Contractonderhoud, Amsterdam.

Rozemeijer F.A., Weele, A.J. van, and Rietveld, G.(1998) 'Professionalizing purchasing organizations: towards a purchasing development model', Proceedings 7th Annual IPSERA Conference, London, pp. 515523.

Rozemeijer, F.A. (2000) Creating corporate advantage in purchasing, ECIS PhD thesis, TU Eindhoven, Eindhoven.

Rozemeijer, F.A., van Weele A.J. and Weggeman, M.C.D.P, (2003) 'Creating corporate advantage in Purchasing: towards a contingency model', International Journal for Supply Chain Management, Vol. 39, No. 1. pp. 4-13.

Rozemeijer (2008) 'Purchasing myopia revisited again?', Journal of Purchasing and Supply Management, Vol. 14, pp. 205-207.

Rüdiger, H. (2009) Evaluating the relationship between the purchasing function maturity, the HRD efforts, the buyer profile and purchasing performance, Master thesis (forthcoming), Maastricht University.

Scarbrough, H. (2000) 'The HR implications of supply chain management', Human Resource Management Journal, Vol. 10, Issue 1, pp. 5-17.

Sengun, A.E. and Wasti, S.N. (2007) Trust, control and risk: a test of Das and Teng's conceptual framework for Pharmaceutical buyer-supplier relationships', Group Organization Management, Volume 32, Issue 4, pp. $430-464$.

Snijder, J. (2002) 'Kostenbewusteloos', ELAN, september.

Snijders, Ch. en Tazelaar, F. (2009) Klapschaatsen in management, Quist, Leidschendam.

Stallkamp, Th. T. (2005) 'Score!: A better way to do business', Wharton School Publishing, New Jersey. 
Tazelaar, F. (2007) 'With a little help from your friends (and neighbours): a potentially faster way to accumulate knowledge in the field of purchasing and supply', Journal of Purchasing and Supply Management, Vol. 13, Issue 3, pp. 196-198.

Tassabehji, R. and Moorhouse, A. (2008) 'The changing role of procurement', Journal of purchasing and supply management, Vol. 14, Issue 1, pp. 55-68.

Telgen, J. (1994) 'Inzicht en overzicht. De uitdagingen van Besliskunde en Inkoopmanagement', Oratie, Universiteit Twente, Enschede.

Trent, R.J. and Monczka, R.M. (1994) 'Effective cross-functional sourcing teams: critical success factors', International Journal of Purchasing and Materials Management, Vol. 30, Issue 4, pp. 3-11.

Trent, R.J. (1996) 'Understanding and evaluating cross-functional sourcing team leadership', International Journal of Purchasing and Materials Management, Vol. 32, Issue 4, pp. 29-36.

Trent, R.J. (1998) 'Individual and collective team effort: a vital part of sourcing team success', International Journal of Purchasing and Materials Management, Vol. 34, Issue 4, pp. 46-54.

Van der Valk, W. and Rozemeijer, F.A. (2009) 'Buying business services: towards a structured service purchasing process', Journal of Services Marketing, Vol. 23, Issue 1, pp. 3-10.

Uzzi, B., (1997) 'Social structure and competition in interfirm networks: the paradox of embeddedness', Administrative Science Quarterly 42 (1), 35-67.

Vos, B. (2004) 'Samen dansen op de vulkaan: de rol van inkoop in dynamische supply chains', Oratie Universiteit van Tilburg.

Van de Vijver, M. (2009) 'Collaboration in Buyer-Supplier Relationship', Proefschrift, Universiteit van Tilburg

Weele, A.J. van (1990) 'Ligt bij Inkoop de eerste winst?', Oratie Technische Universiteit Eindhoven.

Weele, A.J. van (1994) 'Het Nederlandse bedrijfsleven op survival: overleven door uitbesteden', Oratie Technische Universiteit Eindhoven.

Weele, A.J. van and Rozemeijer, F.A. (1996), 'Revolution in Purchasing: building competitive power through proactive purchasing', European Journal of Purchasing and Supply Management, Vol. 2, Issue 4, pp. 153-160.

Weele, A.J. van en Rozemeijer, F.A. (1999) 'Ondernemend Samenwerken: ontwikkelen van concurrentiekracht in netwerken', Kluwer.

Weele, A.J. van (2005) Purchasing and Supply Management, Thomson Learning, London. 
Weele, A.J. van en Rozemeijer, F.A. (2005 'Changing course in corporate procurement, CPO Agenda, pp 45-51.

Wilson, A. (2005) 'A new way to pay purchasing execs', www.Automotive News.com, December 5.

Wong, A., Tjosvold, D. And Yu, Z. (2005) Organizational partnerships in China: self-interest, goal interdependence and opportunism', Journal of Applied Psychology, Vol. 90, Issue 4, pp. 782-792.

Wood, John 'Andy', James S. Boles, Barry Babin, (2008) "The Formation of Buyer's Trust of the Seller in an Initial Sales Encounter," Journal of Marketing Theory \& Practice 16 (1) 27-39.

Wynstra, J.Y.F. (2006) 'Inkoop, Leveranciers en Innovatie: van VOC tot Space Shuttle', Oratie, Erasmus Universiteit Rotterdam. 
Wie kust Doornroosje wakker? 
